\title{
Dividend Changes and Stock Price Informativeness
}

\author{
Amedeo De Cesari and Winifred Huang-Meier*
}

\begin{abstract}
We investigate how private information in stock prices impacts quarterly dividend changes. We find that the positive relationship between past returns and current dividend changes strengthens when returns convey more private information. This finding is robust to the use of several price informativeness measures and the inclusion of managerial private information and stock overvaluation measures. Managers seem to learn new information from stock prices that they use when deciding on their dividend policy. This study highlights private information in stock prices as an important determinant of dividend policy and contributes to the literature on the real effects of financial markets.
\end{abstract}

Keywords: Dividend changes; Stock price informativeness; Stock returns

JEL classification codes: G35, G14

\footnotetext{
* Amedeo De Cesari (amedeo.decesari@mbs.ac.uk) is from Manchester Business School, Booth Street West, Manchester M16 6PB, the United Kingdom. Winifred Huang-Meier (w.huang-meier@aston.ac.uk) is from Aston Business School, Aston Triangle, Birmingham B4 7ET, the United Kingdom.
} 


\section{Introduction}

A commonly-held belief that has informed most finance literature is the notion that corporate insiders possess more complete information on their firm than corporate outsiders. While this is a reasonable belief, we cannot rule out the possibility that outsiders may hold information unknown to insiders that could allow this latter group to make better and more informed decisions. For instance, foreign investors may benefit from information specific to their country's economy that a multinational firm investing in such country does not possess. Firms frequently hire consultants to gain information that may be valuable in the decision-making process. More generally, professional fund managers may be better than industrial firms at analyzing publicly-available information and producing useful private information.

One important channel through which managers can gain novel information on their firm is the observation of the level and dynamics of the firm's valuation on secondary financial markets (Dow and Gorton, 1997; Subrahmanyam and Titman, 1999; Bond et al., 2012). As emphasized by Dow and Gorton (1997) and Chen et al. (2007), stock prices can convey private information possessed by traders on the demand for a firm's products, the firm's investment opportunities, the competitive environment in which it operates, and the implications of the past decisions of the firm's managers. In contrast, traders, unlike the firm's managers, may lack detailed information on the technologies used by the firm. This suggests that stock markets may provide information that is complementary to that held by corporate insiders. Thus, financial markets may not simply be a side show in that they may influence decision makers in the real side of the economy through an informational channel. 
The existing literature on dividend policy, while extensive, has essentially overlooked the role that private information conveyed by stock prices may play as a determinant of cash dividends. Managers can take into account both public and private information when deciding dividend payments. It is well-established in the literature that publicly-available information on variables such as profitability, growth opportunities, and firm size influences dividend policy (e.g., Fama and French, 2001; Grullon and Michaely, 2002). Yet, the link between the private information conveyed by stock prices and dividend policy has received little attention. The main objective of this paper is to fill this gap in the literature. In other words, our study provides important insights into the determinants of dividend policy by taking informed trading into account. To this end, we investigate whether the degree of informativeness of stock market valuations affects the relationship between past abnormal changes in stock prices (i.e. past abnormal returns) and current dividend changes.

We argue that past abnormal stock returns may be considered by managers when deciding whether, in which direction, and to what extent cash dividend payments should be revised. This is because unexpected changes in asset values are informative in that they should reflect news about cash flows and/or discount rates (e.g., Campbell and Shiller, 1988; Chen and Zhao, 2009). News on larger than expected cash flows and/or unexpected decreases in discount rates should generate positive market reactions and may lead managers to increase cash dividends. Thus, consistent with previous evidence (e.g., Grullon et al., 2002; Brown et al., 2007; Chemmanur et al., 2010), we expect current dividend changes to be positively related to lagged abnormal stock returns. However, reporting this positive relationship is not sufficient evidence of managerial learning of private information conveyed by stock price changes. Market investors can, in fact, react to both novel public and private information. In order to distinguish between 
these two types of information we consider several measures of private information in stock prices. Assuming that managers use private information learned from abnormal revisions in market valuations, we expect current dividend changes to be more strongly related to past abnormal returns when more private information is impounded into stock prices.

Despite this, managers could be reluctant to increase dividend payments even after learning novel private information. As highlighted by Jensen (1986) among the others, dividends can be costly to managers because they reduce their freedom to pursue empire-building strategies and engage in other activities that mainly benefit themselves at the expense of their shareholders. Cash dividends can also reduce financial flexibility, potentially leading to underinvestment costs and causing financial distress and managerial job losses (Blau and Fuller, 2008; Bonaimé et al., 2014). However, there is evidence that shareholders can successfully put pressure on managers and force them to be responsive to their demands for dividends, at least in strong investor protection environments (Allen and Michaely, 2003; DeAngelo et al., 2008). For instance, La Porta et al. (2000) show that stronger minority shareholder rights are associated with higher dividend payments. More importantly, managers are likely to also consider the benefits that accrue to them when dividends are paid. They could make dividend payments to shareholders in order to reduce agency costs and boost firm value. A higher firm valuation would benefit managers by decreasing the likelihood of interventions and disciplinary actions by shareholders and making hostile takeovers less probable (Allen and Michaely, 2003; DeAngelo et al., 2008). ${ }^{1}$ Moreover, executive compensation is often linked to equity valuations and managers with large equity investments in their companies may be eager to receive cash dividends to diversify their

\footnotetext{
${ }^{1}$ Even though cash can also be disbursed by repurchasing stock, buybacks are seen by managers and investors as being more flexible than cash dividends. Hence, it is generally argued that paying dividends is a more credible and effective strategy to mitigate agency conflicts and increase firm value.
} 
portfolios (Allen and Michaely, 2003; Brown et al., 2007). When weighing the costs and benefits of cash dividends, news of larger than expected cash flows and/or unexpected reductions in discount rates should make managers more willing to increase dividends mainly owing to the greater availability of cash, higher financial flexibility, and decreased financial distress risk.

Our expectations are tested by using a sample of quarterly dividend changes over the period 1962-2010 for non-financial and non-utility US industrial firms with shares listed on NYSE and AMEX. For a particular firm, the variable dividend change is defined as the difference between the current and the previous quarterly dividend payment, divided by the prior quarterly dividend payment. The average abnormal daily return over the period between the current and the previous quarterly dividend is used as proxy for the lagged abnormal revision in the value of the firm's stock.

Consistent with previous evidence and with our predictions, we report that the likelihood of a dividend increase and the magnitude of a dividend change are both positively related to lagged abnormal stock returns. In contrast, higher past abnormal returns make a dividend cut less likely. More importantly, we find that the degree of informativeness of stock prices, as measured by firm-specific stock return variation (Roll, 1988), strengthens the relationship between lagged abnormal stock returns and dividend changes. Abnormal revisions in the value of a stock are more strongly positively (negatively) associated with future increases (decreases) in dividends when the market valuation of the stock contains more private information that managers can exploit. These relationships are robust to the use of alternative private information measures, namely the illiquidity ratio by Amihud (2002), the trading measure developed by Llorente et al. (2002), and the probability of informed trading (PIN). Further, findings are qualitatively similar when we include a proxy for managerial private information to control for the private 
information conveyed by stock price changes that is already possessed by managers. Finally, we report that the relationships between past returns and current dividend changes become weaker if stocks are overvalued, probably because changes in market valuations are less informative for these stocks that tend to be misvalued. More importantly, after controlling for stock overvaluation in our regressions, we still confirm the main findings of the study.

We can conclude that managers seem to rely more on past abnormal variations in the value of their stock when deciding current dividend changes if such variations are likely to be more informative. Our evidence supports the notion that managers take advantage of novel private information impounded in stock prices when setting the dividend policy of their firms. Consistent with Kau et al. (2008), our study suggests that managers "listen to the market" since changes in corporate policies are sensitive to market reactions. More generally, our study contributes to the growing literature on the effects of secondary market stock prices on corporate financial decisions. Notable previous studies focus on investments (e.g., Wurgler, 2000; Durnev et al., 2004; Chen et al., 2007), CEO turnover (Defond and Hung, 2004), mergers and acquisitions (Luo, 2005), and cash savings (Fresard, 2012). ${ }^{2}$ Our findings fill a gap in this literature by highlighting that dividend decisions are affected by information learned by managers from stock price changes.

Moreover, our study focuses on a policy that financial managers consider as important as the investment policy of their firms (Brav et al., 2005). Dividend payments involve large sums of money, are quite frequent transactions (i.e. every quarter in our study) that can generate large market reactions, and are interconnected with key financial decisions regarding real investments,

\footnotetext{
${ }^{2}$ Our study is related to the catering theory of dividends developed by Baker and Wurgler (2004) in that it shows that stock market valuations influence dividend payments. Yet, while Baker and Wurgler (2004) consider timevarying market-wide measures of investor demand for dividends, we focus on firm-specific changes in stock valuations and argue that dividend changes are partly associated with the information conveyed by such changes.
} 
issues of debt and equity, mergers and acquisitions, and the retention of earnings (Allen and Michaely, 2003). Enhancing our understanding of which variables affect dividend policy is, therefore, useful to build better theories and explanations concerning other corporate finance decisions. Important implications, both for managers and shareholders, arise from our study. It highlights the notion that managers can potentially optimize their dividend policy by exploiting information conveyed by stock price changes. Shareholders can also use such information to ascertain whether the future prospects of their firms are improving and larger dividend payments should be expected. Overall, this study offers an important contribution to the corporate finance literature.

The paper is structured as follows. In Section 2 we review the existing literature and discuss the research questions. Section 3 describes the data used in this study and the empirical methods. In Section 4 we present and discuss the empirical findings, including those from several robustness tests. Section 5 provides concluding remarks.

\section{Related literature and research questions}

In this section, we summarize prior studies of the relationship between the information content of stock prices and corporate decision-making. We also analyze literature on the interrelations between stock returns, price informativeness, and dividend changes. Our research questions are discussed and motivated at the end of this section.

\subsection{The informational role of financial market prices in managerial decision-making}


In recent years, there has been growing interest in the effects of secondary market prices on decisions taken by individuals in the real side of the economy. For instance, an argument that is often advanced is that corporate insiders can gain useful information from stock market valuations to make better and more informed decisions (e.g., Dow and Gorton, 1997; Subrahmanyam and Titman, 1999). In their comprehensive review of the existing literature, Bond et al. (2012) posit that financial market prices are significantly meaningful to "real decision makers" for three main reasons. First, market prices convey useful information to decision makers. For instance, stock prices contain information about the firm's investment opportunities and the managers' past decisions (Dow and Gorton, 1997). Second, decision makers take market prices into account even if they do not learn any genuinely novel information from them. Third, behavioral biases affect decision makers and lead them to irrationally rely on market prices and use them as anchors.

In this paper, we focus on the first argument above and, more specifically, on the links between stock market prices and decisions by corporate managers. As highlighted by Bond et al. (2012), while a corporate insider is probably more informed than the average outsider, stock market prices may still be useful to imperfectly informed managers simply because they may not have some information that traders have. The market value of a company, in fact, reflects aggregate information from a very large set of outside investors. Further, corporate outsiders may possess more complete external information than insiders that can also be important in the context of managerial decisions.

The existing empirical literature supports the notion that corporate decision makers learn useful information from financial markets. Several authors have studied corporate investment policy. For instance, Wurgler (2000) studies the financial markets of 65 countries and reports 
that the efficiency of capital allocation is positively correlated with the amount of firm-specific information in stock returns. He argues that more informative prices allow managers to better distinguish between good and bad investment opportunities through more reliable Tobin's Q measures. Similarly, Durnev et al. (2004) find support for the prediction that more informative stock prices should enhance capital budgeting decisions. Chen et al. (2007) show that stock price informativeness has a positive effect on the sensitivity of corporate investment to stock price. They also report that price informativeness measures are associated with future firm operating performance. This evidence suggests that private information conveyed by stock prices allow managers to learn about their firms' fundamentals and enhance managerial corporate investment decisions. Relatedly, Foucault and Fresard (2014) report a stronger positive relationship between a firm's investments and the valuations of its peers when the firm's stock price is less informative and when the firm's managers possess less information. Bakke and Whited (2010) show that while stock market mispricing does not influence investments, managers use private information in stock market prices when deciding their investment policy. From a related perspective, Kau et al. (2008) document that managers listen to the market and tend to abandon investment projects when the market reacts negatively to the related announcements.

The real effects of financial markets have also been studied in relation to other corporate events and policies. For example, in countries with strong law enforcement, there is evidence of a more significant relationship between CEO turnover and poor stock performance when stock prices are more informative (Defond and Hung, 2004). This finding indicates that executives are more likely to be evaluated using the stock market performance of their companies when more firm-specific information is impounded in stock prices. A relationship between the market reaction to an M\&A announcement and the completion of the deal is reported by Luo (2005). It 
appears that companies involved in an M\&A deal extract information from the investor reaction to the announcement of the transaction in order to decide how to proceed with the deal. Finally, Fresard (2012) concentrates on cash savings and reports a higher savings-to-price sensitivity when stock price is more informative. On the whole, a growing literature documents that the information content of stock prices is endogenous to corporate decisions such as investment and cash policy decisions.

\subsection{Stock returns, price informativeness, and dividend changes}

Managers can use both public and private information to decide their companies' dividend policies. There is no lack of literature reporting significant relationships between lagged and current values of publicly-known variables such as profitability, growth opportunities, and firm size and cash dividends (e.g., Fama and French, 2001; Grullon and Michaely, 2002). Since managers may learn from stock prices when making decisions, an important research question to address is whether such learning influences decisions on dividend changes.

It has been argued that managers change the level of dividend payments for different reasons. Some authors argue that dividends can convey information about future cash flows (Miller and Modigliani, 1961) and that managers may use dividend changes as costly signals of future earnings changes (Miller and Rock, 1985; Bhattacharya, 1979; John and Williams, 1985). Based on their arguments, we could expect dividend increases (decreases) to be followed by positive (negative) changes in profitability and cash flows. However, with few exceptions (e.g., Nissim and Ziv, 2001), the research on dividend increases has not provided support to this expectation. For example, Benartzi et al. (1997) find that companies that increase dividends do

not benefit from unexpected future positive changes in earnings. Similar evidence on firm 
performance has been reported by DeAngelo et al. (1996), Grullon et al. (2002), and Grullon et al. (2005). ${ }^{3}$ As for dividend cuts, while DeAngelo et al. (1992) show that they may be useful to predict future earnings, other studies show insignificant or even positive changes in firm performance after a reduction in cash dividends (e.g., Benartzi et al., 1997; Grullon et al., 2005; Jensen et al., 2010).

Changes in dividend payments may also convey information about future risk levels. Grullon et al. (2002) find that the systematic risk of firms that increase (decrease) their dividends significantly declines (rises) after the dividend change. They highlight that these empirical results are consistent with the argument that firms start paying higher dividends when they become more mature and have fewer investment opportunities. This "maturity hypothesis" explains both the declining systematic risk following dividend increases and the lack of a positive association between dividend changes and future profitability. Other related studies find that operating income volatility (Lie, 2005) and default risk (Charitou et al., 2011) decline around dividend increases.

In summary, the existing dividend literature suggests that companies use information on lagged and current values of several variables (e.g. profitability) together with expectations on other variables (e.g. systematic risk) when deciding whether, to what extent, and in which direction they should adjust their dividend policy. Both public and private information can help companies optimize their dividend payments. As mentioned above, the usefulness of private information conveyed by outside investors through trading has been overlooked in prior research. In this paper, we aim to fill this gap by investigating whether private information

\footnotetext{
${ }^{3}$ Studies of dividend initiations offer mixed conclusions. For instance, Healy and Palepu (1988) find that initiations signal future earnings growth whereas Bulan et al. (2007) show that profitability and growth do not improve after a company starts paying dividends.
} 
conveyed by lagged abnormal changes in the market valuation of a company is used by the company's managers to decide changes in dividend policy. This is because dividend announcements are generally made every quarter. Our aim is to investigate whether managers take private information in stock prices into account when they make frequent decisions. We focus on abnormal stock returns because unexpected changes in asset values should reflect and, therefore, convey news about cash flows and/or news about discount rates (e.g., Campbell and Shiller, 1988; Chen and Zhao, 2009). For instance, the empirical study of Chen et al. (2013) reports that both cash flow and discount rate news affect unexpected movements in stock prices in a significant way.

When investor expectations on the cash flows produced by a stock are revised upward, the market value of the stock should increase. In contrast, higher expectations on discount rates should depress market valuations. We thus expect to find a positive relationship between dividend changes and lagged abnormal stock returns, also in light of prior empirical findings (e.g., Grullon et al., 2002; Brown et al., 2007; Chemmanur et al., 2010). However, identifying such relationship is not enough to conclude that companies exploit new private information learned from stock price movements when setting their dividend policy. New public information from other sources may, in fact, drive both amendments in dividend policy and variations in stock market valuations.

In our study, we go a step further and test whether lagged abnormal returns have more significant effects on dividend changes when stock prices are more likely to impound and convey investor private information. Assuming that managers can learn useful private information from variations in stock prices, we expect that more private information in stock prices would make the positive relationship between dividend changes and lagged abnormal stock returns stronger. 
When testing this prediction, we also attempt to control for managerial private information in order to separate the effects of this information from that potentially learned by managers from past stock price changes. Finally, since stock returns are likely to be less informative when stocks tend to be misvalued, in some of our analyses we investigate the robustness of our findings to the inclusion of market misvaluation proxies.

\section{Sample, data and empirical methods}

\subsection{Sample of dividend changes}

We consider announced dividend payments to compute our Dividend change variable. Dividend announcements are selected from CRSP mainly following the filters of Grullon et al. (2002). To be specific, we include dividend announcements made by NYSE and AMEX firms between 1962 and 2010 that satisfy the following criteria:

a) The announcement is for a quarterly cash dividend payment in US dollars;

b) The dividend payment is not an initiation (i.e. there is a quarterly cash dividend payment in the previous quarter);

c) The previous quarterly cash dividend payment was made within a window of 20 to 90 days before the current dividend announcement;

d) The dividend payment is not made by a firm that is either a utility firm (SICs 4900 to 4949) or a financial firm (SICs 6000 to 6999);

e) The CRSP share code for the firm announcing the dividend payment is either 10 or 11 . 
Dividend change is the quarterly dividend announced in the current quarter minus the quarterly dividend announced in the previous quarter, all divided by the quarterly dividend for the previous quarter. This variable can take positive, negative, and zero values. After excluding observations with missing values for the other variables used in the study, our baseline sample includes 98,535 observations for 2,510 unique firms with valid values of the variable Dividend change. In this sample, there are 16,240 observations for 1,994 unique firms with non-zero values of Dividend change.

\subsection{Baseline specification and data sources}

In order to study how the sensitivity of dividend changes to lagged abnormal returns varies with private information in stock prices, we employ the following baseline model:

\section{Dividend change $e_{i, q}$}

$$
\begin{aligned}
& =\beta_{0}+\beta_{1} \text { Abnormal return }_{i, q}+\beta_{2} \text { Private information }_{i, q} \\
& \left.+\beta_{3} \text { (Abnormal return }_{i, q} \times \text { Private information }_{i, q}\right)+\beta_{4} \text { Dividend yield }_{i, q} \\
& +\beta_{5} \text { Market capitalization }_{i, q}+\beta_{6} \text { Debt }_{i, q}+\beta_{7} \text { Cash }_{i, q} \\
& +\beta_{8} \text { Market-to-book }_{i, q}+\beta_{9} \text { Operating income }_{i, q}+\beta_{10}{\text { Dividend } \text { premium }_{i, q}} \\
& +\varepsilon_{i, q}
\end{aligned}
$$

where $i$ identifies the firm that is announcing the quarterly dividend payment and $q$ is the quarter when the announcement takes place. The inclusion of the interaction term Abnormal return $\times$ Private information allows us to test whether the level of private information in stock prices has a significant impact on the relationship between dividend changes and lagged abnormal returns. 
Stock market data such as quarterly dividend payments, stock returns, trading volumes, turnovers, dividend yields, and market capitalizations are collected from CRSP. Compustat is our source of accounting data. Our study also uses Søren Hvidkjær's data, available from his website $^{4}$, to measure the probability of informed trading (PIN) as one of our alternative proxies for stock price informativeness. Definitions for all the independent variables can be found in the following sections.

In all our regressions we control for two-digit SIC industry dummies. ${ }^{5}$ Standard errors are adjusted for two-way clustering by firm and calendar month. In order to minimize the influence of very large abnormal stock returns that could possibly reflect major corporate events, we trim $1 \%$ of the observations from each tail of the distribution of Abnormal return. Similarly, both tails of the distributions of all the other variables used in this study are winsorized at the top and bottom $1 \%$ level.

\subsection{Abnormal return}

We follow a method similar to that used by Faulkender and Wang (2006) to compute the abnormal returns. Specifically, we define the abnormal return as the return in excess of the value-weighted return for the relevant Fama-French benchmark portfolio. For each Dividend change event, the benchmark portfolio is selected from the set of 25 Fama-French portfolios formed on size (i.e. market value of equity ME) and book value over market value of equity (BE/ME). To identify the relevant portfolio, we consider firm-specific ME and BE/ME values and use matching criteria in accordance with the methods originally followed to create the

\footnotetext{
${ }^{4}$ https://sites.google.com/site/hvidkjaer/data.

${ }^{5}$ Results are qualitatively similar if we also control for calendar month dummies. The only significant difference is that coefficients for Dividend premium become insignificant in all regressions when month dummies are included.
} 
portfolios. ${ }^{6}$ Over the pre-event period, Abnormal return, which is expressed in percent terms, is the average daily difference between the return on the stock and the return on the relevant benchmark portfolio. ${ }^{7}$ The pre-event period for this computation is the period between the previous and the current quarterly dividend announcements. However, we do not use data for the five trading days before the current dividend announcement and the five trading days after the previous dividend announcement. These exclusions are meant to minimize and/or eliminate the impact of the market reactions to dividend announcements on our abnormal return estimates.

A positive (negative) Abnormal return can be seen as an indication that, during the period between the current and the previous dividend announcements, market investors have increased (decreased) their valuation of the stock following the acquisition of novel information that was unknown to investors at the time of the previous dividend announcement.

\subsection{Measures of private information in stock market prices}

A widely used measure of private information in stock prices is firm-specific stock return variation (or price nonsynchronicity). This measure, which was firstly developed by Roll (1988), reflects the variation in the return on a stock that cannot be explained by market and industry returns. For a generic stock $i$, firm-specific return variation can be defined as $\psi=$ $\ln \left(\left(1-R^{2}\right) / R^{2}\right)$, where $R^{2}$ is estimated from the following regression:

\footnotetext{
${ }^{6}$ Each calendar year, the Fama-French portfolios and their respective breakpoints are generated at the end of June. For daily stock returns of a firm between July $1^{\text {st }}$ of year $t$ and June $30^{\text {th }}$ of year $t+1$, we use the year $t$ breakpoints and the following firm-specific variables to select a suitable benchmark portfolio. The firm's ME is measured at the end of June of year $t$ while BE/ME is the ratio between BE for the fiscal year ending in calendar year $t-1$ and ME as of the end of the same year. Portfolio value-weighted returns and portfolio breakpoints are obtained from Kenneth French's website (http://mba.tuck.dartmouth.edu/pages/faculty/ken.french/).

${ }^{7}$ For the same period, we consider several alternative measures of abnormal return. First, we simply use the average daily return on the stock, essentially assuming that the benchmark portfolio produces a zero return. Second, we run daily time-series regressions to estimate two versions of Jensen's Alpha, one based on the three Fama-French risk factors and one augmented by the momentum factor. We replicate all our analyses replacing Abnormal return with these alternative measures and find qualitatively similar results.
} 


$$
r_{i, j, t}=a_{i}+b_{i, m} r_{m, t}+b_{i, j} r_{j, t}+\varepsilon_{i, t}
$$

where $r_{i, j, t}$ is the return for firm $i$ that is part of industry $j$ at time $t, r_{m, t}$ represents the market return at time $t$, and $r_{j, t}$ is the return for industry $j$ at time $t$. The market return is based on the CRSP value-weighted market portfolio and firms are grouped into industries using 3-digit CRSP SIC codes. We exclude firm $i$ from the market and industry indices when we calculate market and industry returns. For each dividend change announcement in our sample, we estimate its firm-specific return variation $(\psi)$ using daily stock, market, and industry returns over the calendar year before the announcement date. ${ }^{8}$

Roll (1988) argues that firm-specific return variation may be correlated with private information. He, in fact, finds that identifiable news releases do not drive firm-specific return variation. Since movements in stock prices are generally caused by either releases of new public information (e.g. corporate earnings and GDP figures) or by trades of investors possessing private information, Roll's findings may suggest that only this latter type of information is associated with price nonsynchronicity. However, as conceded by the author, trades by uninformed noise traders could also produce changes in stock prices that are unrelated to market and industry returns.

Despite this cautionary note, a large and growing body of empirical research lends credence to the notion that firm-specific return variation is a valid measure of private information in stock prices. The empirical research that validates this measure in the most convincing way is probably Durnev et al. (2003). This study reports a negative relationship between $R^{2}$ and the

\footnotetext{
${ }^{8}$ This period could overlap with that for the calculation of Abnormal return. We evaluate whether this circumstance affects our findings by using, instead, lagged values of firm-specific return variation and the other private information measures. We confirm that the main findings of our paper are qualitatively similar when lags are used.
} 
strength of the association between current stock returns and future earnings. This result implies that the information impounded in current stock prices is more useful to predict future earnings when firm-specific return variation represents a larger fraction of total return variation.

Relatedly, Morck et al. (2000) provide evidence of a lower level of firm-specific return variation in low-income economies and of a declining trend in price synchronicity in the U.S. Durnev et al. (2004) report that the efficiency of corporate investments is an increasing function of firm-specific return variation. This empirical regularity suggests that less synchronous prices convey more private information that managers use to enhance their investment policy. Piotroski and Roulstone (2004) find price synchronicity to be positively associated with the activity of financial analysts. In contrast, they show that trades by insiders have a negative effect on synchronicity. Finance researchers have very frequently chosen firm-specific return variation as a measure of private information in stock prices. ${ }^{9}$

In spite of firm-specific return variation being a widely used measure of private information in stock prices, some recent studies cast doubts on the reliability of this measure. Through a simple model and consistent empirical findings, Dasgupta et al. (2010) show that, contrary to conventional wisdom, a more transparent information environment should be associated with higher stock return synchronicity. Xing and Anderson (2011) report a nonmonotonic relationship between price synchronicity and proxies of public firm-specific information. Assuming an inverse association between private and public firm-specific

\footnotetext{
${ }^{9}$ The measure can be found in empirical studies of capital allocation and investments (Wurgler, 2000; Chen et al., 2007; Bakke and Whited, 2010; Foucault and Fresard, 2014), cash savings (Fresard, 2012), CEO turnover (Defond and Hung, 2004), private benefits of control (Dyck and Zingales, 2004), analyst coverage (Chan and Hameed, 2006; Crawford et al., 2012), stock market opaqueness (Jin and Myers, 2006; Hutton et al., 2009), corporate governance characteristics (Ferreira and Laux, 2007; Ferreira et al., 2011), cross-listings (Fernandes and Ferreira, 2008), block ownership (Brockman and Yan, 2009), insider trading laws (Fernandes and Ferreira, 2009), and the association between asset growth rates and stock returns (Watanabe et al., 2013).
} 
information, this finding undermines the notion that private information varies monotonically with synchronicity. Similarly, Lee and Liu (2011) report U-shaped relations between firmspecific return variation and several alternative price informativeness measures. Chan and Chan (2014) report a negative relation between stock return synchronicity and SEO discount and conclude that the informativeness of stock prices grows with return synchronicity. In light of the recent studies above and to evaluate the robustness of our findings, in our study we consider several alternatives to stock price nonsynchronicity.

The illiquidity ratio (Illiq), introduced by Amihud (2002), has been recently used as a price informativeness measure by Ferreira et al. (2011) and Fresard (2012). This variable is the average (multiplied by $10^{6}$ ) of the daily ratio between the absolute value of the return on a stock and the stock's dollar volume:

$$
\text { Illiq }_{t}=\frac{1}{D_{i}} \sum_{t=1}^{D_{i}} \frac{\left|r_{i, t}\right|}{\text { Volume }_{i, t}}
$$

where $D_{i}$ is the number of valid daily observations for firm $i$ over the period, while $\left|r_{i, t}\right|$ and Volume $_{i, t}$ are, respectively, the absolute value of the return and the dollar volume for firm $i$ at time $t$. Illiq is computed for each dividend change announcement using daily data for the calendar year before the announcement as long as there are at least 200 trading days with nonzero trading volume. The application of this filter allows us to discard observations for thinly traded stocks. The illiquidity ratio is a proxy for the price impact of trades because it measures the extent to which stock transactions cause stock prices to change. Thus, in the spirit of the model by Kyle (1985), this ratio should also reflect the informativeness of stock market transactions. 
We also consider the private information trading measure of Llorente et al. (2002). Examples of studies that have chosen this measure are Ferreira and Laux (2007), Fernandes and Ferreira (2008), Fernandes and Ferreira (2009), and Fresard (2012). We run the following regression to estimate the measure of information-based trading $\gamma$ :

$$
r_{i, t}=a_{i}+b_{i} r_{i, t-1}+c_{i} r_{m, t}+\gamma_{i}\left(r_{i, t-1} * V_{i, t-1}\right)+\varepsilon_{i, t}
$$

where $r_{i, t}$ is the return for firm $i$ at time $t, r_{m, t}$ represents the market return at time $t$ (based on the CRSP value-weighted market return), and $V_{i, t-1}$ is the logarithm of firm $i$ 's turnover at time $t-1$, detrended by subtracting its average value in the previous 200 trading days. ${ }^{10}$ The coefficients of the regression above are estimated for each dividend change announcement using daily return and turnover data for the calendar year preceding the announcement. In the model by Llorente et al. (2002), the coefficient $\gamma$ is normally interpreted as a measure of information-based trading. The intuition behind this interpretation is that stock returns should be more positively serially correlated when trades by informed investors are more frequent.

The final price informativeness proxy we consider is the probability of informed trading (PIN) measure of Easley et al. (2002). This measure is based on a market microstructure model in which trades can be executed by noise or informed traders. PIN has been chosen as a proxy of private information in stock prices by many studies. Notable examples are Chen et al. (2007), Ferreira and Laux (2007), Brockman and Yan (2009), and Ferreira et al. (2011). We obtain all available yearly estimates of the PIN, from 1983 to 2001, for our sample of NYSE/AMEX common stocks from the aforementioned source - Søren Hvidkjær's website. For a particular

\footnotetext{
${ }^{10}$ In order to keep observations with zero daily turnovers, we follow Llorente, et al. (2002) and add 0.00000255 to the actual turnover before applying the logarithmic transformation.
} 
dividend change announcement, we consider the PIN for the latest calendar year before the announcement.

\subsection{Control variables}

We control for several variables that have been shown to be significant determinants of changes in quarterly dividends in the previous literature. In particular, we rely on the set of controls used by Li and Lie (2006) that includes Dividend yield, Market capitalization, Debt, Cash, Market-to-book, Operating income, and Dividend premium.

Dividend yield is the CRSP annual return from dividend payments. Market capitalization (in billion US dollar and deflated to 1980 using the CPI) is the CRSP market value of equity. Debt is the ratio of long-term debt (Compustat item 9) to total assets (Compustat item 6). Cash is cash and short-term investments (Compustat item 1) over total assets (Compustat item 6). Market-to-book is the market value of assets divided by the book value of assets (Compustat item 6). The market value of assets is defined as the book value of assets minus the book values of common equity (Compustat item 60) and deferred taxes (Compustat item 74), plus the market value of equity (Compustat item 199 times Compustat item 25). Operating income is operating income before depreciation (Compustat item 13) scaled by total assets (Compustat item 6). Following Baker and Wurgler (2004), we define Dividend premium as the difference between the $\log$ of the value-weighted average market-to-book ratio of dividend payers and the same measure for non-dividend payers. We carefully replicate the steps followed by Baker and Wurgler (2004) to compute this variable for every year in our sample period. However, in order to be consistent with our sample of dividend changes that only includes observations for NYSE and AMEX firms, we exclude data for NASDAQ companies when building the Dividend premium variable. 
Except for Market capitalization and Dividend premium, we consider lagged values of all control variables for fiscal periods ending before the date of the current quarterly dividend announcement that is used to compute the Dividend change variable. The variable Market capitalization is based on data from one day prior to the current quarterly dividend announcement. Dividend premium is for the latest calendar year immediately before the announcement of the current quarterly dividend.

\section{Empirical findings}

\subsection{Descriptive statistics}

The descriptive statistics for all the variables included in our baseline specifications are presented in Table 1. The average value of Dividend change (2.2\%) shows that, on average, companies increase their quarterly dividends rather than cutting them or keeping them unchanged. However, the median value of Dividend change is 0 and this variable ranges from a minimum that is just below zero to a very large value of $40 \% .{ }^{11}$ Only in 1,366 cases the change in quarterly dividends is negative while a zero change in dividends is very common.

[Insert Table 1 here]

It is also worth noting that announcements of quarterly dividend changes are generally preceded by positive abnormal changes in stock prices since the mean Abnormal return is $0.0018 \%$. However, the range of variation of this variable is very wide. The descriptive statistics for some of the other variables indicate that, on average, the Dividend yield is $3.66 \%$, and long-

\footnotetext{
${ }^{11}$ The winsorization that is applied to the extreme values of Dividend change significantly increases the minimum value of this variable. The pre-winsorization minimum value of the variable is around -0.9792 .
} 
term debt and cash and short-term investments represent $18.72 \%$ and $8.13 \%$ of total assets respectively. Finally, the mean (median) value of Operating income is $16.74 \%$ (15.97\%).

\subsection{Firm-specific stock return variation and dividend changes}

In our first set of multivariate analyses, we consider firm-specific stock return variation $(\psi)$ as proxy for the private information impounded in stock prices. Also, we use Multinomial Logit regressions to estimate the baseline specification of equation (1). To build our categorical dependent variable, we consider the following three possible outcomes based on the variable Dividend change: the value of Dividend change is zero (no changes in dividends), positive (dividend increases), or negative (dividend decreases). We focus on dividend increases and decreases separately by using the first outcome (no change in quarterly dividends) as the base case. ${ }^{12}$ Empirical estimates for three Multinomial Logit models can be found in Table 2.

\section{[Insert Table 2 here]}

In columns (1) and (2) of Table 2, the set of independent variables comprises Abnormal return together with all the standard controls. As expected, there is a positive and statistically significant relationship between Abnormal return and the likelihood of a dividend increase (column (1)). In contrast, an increase in Abnormal return makes a dividend cut less likely (column (2)). Firms tend to increase (decrease) dividends after a period of strong (weak) stock market performance. However, these findings may not necessarily indicate that managers learn new information from recent stock price changes that they exploit when determining dividend

\footnotetext{
${ }^{12}$ We have also estimated a Logit model in which the dependent variable is a dummy that is set to one when Dividend change is not equal to zero. Otherwise, the dependent variable is set to zero. Since the great majority of non-zero dividend changes are increases, the results of the Logit model are qualitatively similar to the Multinomial Logit findings for positive dividend changes.
} 
changes. For instance, the disclosure of unexpected news on a company may, at the same time, affect its market valuation significantly and cause future variations in dividend payments.

Next, we consider a measure of private information in stock prices. By adding this measure to our models, we can test whether managerial payout decisions are more consistent with the sign and magnitude of recent stock price changes when such changes convey more private information. In columns (3) and (4), we replace Abnormal return with the firm-specific stock return variation $\psi$. We find that this measure of private information in stock prices has a statistically significant negative effect on dividend increases. The empirical findings suggest that positive changes in quarterly dividends become more likely if the stock of the firm conveys less private information. In columns (5) and (6), we include Abnormal return, the firm-specific stock return variation, and, more importantly, the interaction between these two variables. The signs of the coefficients on Abnormal return and $\psi$ confirm the conclusions from the previous columns of Table 2. Of greater importance, in column (5), the coefficient on the interaction term Abnormal return $\times \psi$ is positive and highly statistically significant. This suggests that firm-specific stock return variation strengthens the positive relationship between the likelihood of a positive change in dividends and the recent abnormal stock performance. A similar conclusion can be drawn in relation to the probability of dividend cuts (column (6)): the negative impact of the pre-event abnormal return on such probability becomes larger when $\psi$ increases. Since firm-specific stock return variation measures the extent to which private information is impounded in stock prices, these findings suggest that managers are more likely to alter dividend levels following abnormal changes in stock valuations when stock returns convey more private information.

In Table 2, coefficient estimates for other independent variables generally have the expected signs. High dividend yields make dividend cuts more likely and reduce the probability 
of dividend increases. In contrast, large and profitable firms tend to increase dividend payments whereas the likelihood of a dividend cut is greater for small firms with low profits (see findings for Market capitalization and Operating income). There is a negative (positive) relationship between Market-to-book and the likelihood of dividend increases (decreases), implying that firms with better investment opportunities tend to pay lower dividends as they value cash more.

Table 3 replicates the three specifications of Table 2 using Ordinary Least Squares (OLS) regressions. The dependent variable in Table 3 is the relative change in successive quarterly dividends (Dividend change). As noted above, in the great majority of occurrences quarterly dividends are not changed in our sample. Since we are primarily interested in dividend increases and decreases following abnormal changes in stock prices, in our continuous models we drop the observations with zero changes in quarterly dividends. ${ }^{13}$

[Insert Table 3 here]

Confirming the empirical outcomes of the Multinomial Logit regressions, in column (1) of Table 3 we find that the coefficient on the variable Abnormal return is positive and statistically significant. Larger recent abnormal stock returns lead to greater changes in quarterly dividend payments. In column (2), we report a statistically significant negative impact of $\psi$ on Dividend change. Companies with more private information in stock prices tend to choose smaller relative changes in their quarterly dividends. More importantly, we show that firm-

\footnotetext{
${ }^{13}$ We test whether our key findings are driven by this choice and estimate several regression models using samples that also include observations with zero changes in quarterly dividends. An econometric challenge we face is due to the fact that the distribution of dividend changes has a mass point at zero. At the same time, dividend changes can also be negative, even though dividend decreases are very infrequent. We, therefore, rely on two different types of Tobit models to re-estimate the specifications of Tables 3 and 5. In the first type of Tobit model, we set the variable Dividend change to zero whenever there is a dividend decrease. In the second, observations with dividend decreases are dropped. Hence, the distributions of the samples we use in the Tobit regressions have a corner solution outcome at zero. A Tobit estimation technique is particularly suitable in this case. Overall, the estimates of the Tobit models provide findings for the interactions between Abnormal return and the measures of private information in stock prices that are qualitatively similar to those reported in Tables 3 and 5.
} 
specific stock return variation amplifies the effect of the pre-event abnormal returns on current quarterly dividend changes (see the result for the interaction term in column (3)). Dividendsetting managers seem to find stock price changes more meaningful and informative when stock prices are more likely to impound and convey private information.

Other statistically significant findings from Table 3 indicate that quarterly dividend changes tend to decrease with the Dividend yield, the Market-to-book ratio, and, surprisingly, Market capitalization. On the other hand, companies with greater values of the variables Operating income and Dividend premium choose larger changes in quarterly dividend payments.

\subsection{Alternative measures of private information in stock prices}

To investigate the robustness of our results, we perform additional tests. We consider a set of alternative measures comprising the illiquidity ratio (Illiq) by Amihud (2002), the private information trading measure $(\gamma)$ created by Llorente et al. (2002), and the probability of informed trading $(P I N)$. Increases in the values of any of these measures should be associated with more private information in stock prices. On the whole, the key findings, although statistically weaker than when considering the firm-specific return variation, are qualitatively unaffected by the use of these alternative private information measures.

Estimates for several Multinomial Logit models can be found in Table 4. Coefficients on Abnormal return are generally statistically significant and they have the expected signs. They are positive in regressions of dividend increases and negative in models for dividend cuts. Interaction terms between Abnormal return and private information measures are positively related with the likelihood of dividend increases. Further, these relationships are statistically significant at standard levels except in the specification for $\gamma$. While the results for positive 
dividend changes confirm what is reported in Table 2, regressions findings for dividend cuts are less supportive since they are statistically insignificant.

\section{[Insert Table 4 here]}

Moving on to models with the continuous Dividend change dependent variable (Table 5), we again find that greater recent abnormal changes in stock prices are followed by larger relative changes in quarterly dividend payments. More importantly, this relationship gets stronger when stock price changes are more informative, i.e. when stock market valuations reflect and convey more private information that managers may not possess. It is, in fact, the case that the coefficients on all the interaction terms between Abnormal return and measures of private information in stock prices are positive. However, the coefficient on Abnormal return $\times$ PIN is not statistically significant possibly owing to the smaller sample size.

\section{[Insert Table 5 here]}

After further investigating our research question by exploiting several alternative measures of private information in stock prices, we can state that the conclusions drawn in relation to the firm-specific stock return variation hold. Past abnormal stock returns exercise a far more significant impact on the extent of current dividend changes when they are more likely to be informative for managers. To wit, private information in stock prices strengthens the impact of past revisions in stock prices on current variations in dividend payments.

\subsection{Managerial private information}

The empirical findings we have highlighted so far suggest that managers learn from recent stock price changes and obtain precious information that they take into account when 
deciding changes in quarterly dividends. However, the private information measures of this study do not allow us to distinguish between information that is in the exclusive domain of outside investors and information that is shared by insiders and outsiders at the same time. Abnormal increases in stock prices may be caused by trades from outside investors acting upon recentlyacquired private information. Following such price changes, managers may go ahead with dividend increases either because they learn new information from the recent variations in stock prices or because they more directly possess the same information that outsiders exploited when trading stock.

We recognize that it is not feasible to precisely separate the private information that is directly and independently acquired by managers in the period preceding a dividend announcement from what is learned from recent stock price changes. Nevertheless, in our empirical tests, we attempt to control for the level of private information that is held by managers. To do so, we follow Chen et al. (2007) and Fresard (2012) and use the variable earnings' surprise $(E R C)$ as a proxy of managerial private information. This is the average of the absolute market-adjusted returns generated by the four quarterly earnings announcements (from Compustat) that precede the current announcement of a quarterly dividend payment. We use the CRSP value-weighted market return and three-day windows around the earnings announcements to compute the market-adjusted returns. Intuitively, ERC should reflect the extent to which investors are surprised by earnings announcements. If managers do not possess significant private information that gives them a large informational advantage over outsiders, investors' reactions to earnings announcements should be quite muted. In contrast, when managers hold very significant private information, earnings surprises should be quite substantial. 
In order to control for managerial private information and following the approach of Chen et al. (2007) and Fresard (2012), we add the variable ERC and the interaction of this variable with Abnormal return to all our multivariate specifications. ${ }^{14}$ Starting from the Multinomial Logit models of Table $6^{15}$, we observe a statistically significant negative (positive) effect of ERC on the probability of a dividend increase (decrease). The coefficient on the interaction Abnormal return $\times E R C$ is positive but insignificant in most models. Except in models for $\gamma$, consistent with the results from Tables 2 and 4 , coefficients on the interaction terms between Abnormal return and the measures of private information in stock prices are positive and statistically significant at standard levels in the specifications for dividend increases. They are negative and significant in dividend cut specifications.

[Insert Table 6 here]

The OLS models reported in Table 7 use the continuous variable Dividend change. After controlling for $E R C$, the results confirm the positive relationships between Dividend change and the interaction terms of Abnormal return with the measures of private information in stock prices. Overall, our evidence shows that the pre-event Abnormal return has a larger influence on dividend change decisions for managers acquiring novel, private information from stock prices.

[Insert Table 7 here]

\subsection{Stock market overvaluation}

\footnotetext{
${ }^{14}$ By including this interaction term we essentially test whether the findings for the interactions between Abnormal return and the measures of private information in stock prices are actually driven by the availability of private information by managers that could be correlated with such measures. In untabulated analyses, we also test whether the findings presented in this section are robust to the inclusion of interaction terms between $E R C$ and the measures of private information in stock prices. We can confirm the robustness of our main results. Further, if the triple interaction term between Abnormal return, private information in stock prices, and ERC is added to our specifications, the coefficients on this term are always statistically insignificant.

${ }^{15}$ For the sake of brevity, in Tables 6-9 we do not report coefficients for the full set of control variables. Findings for the omitted variables are qualitatively similar to those in Tables 2-4.
} 
In a market with well-informed, rational investors, unexpected changes in stock valuations are driven by reliable novel information on future cash flows and discount rates. In our study, we essentially assume that past abnormal returns may affect managerial choices on future dividend changes since abnormal returns are primarily generated by trades from informed investors. While this assumption may be plausible, we cannot rule out the possibility that transactions by poorly informed noise traders could also produce significant effects on stock market valuations. The several private information measures we use should help us distinguish between informative and uninformative past changes in stock prices. The findings we report above suggest that these measures successfully achieve this goal since we report a stronger relationship between past abnormal returns and current dividend changes when stock price changes convey more private information.

Nevertheless, to directly control for the potential effects of noise trading, we extend our baseline analyses by considering a measure of stock overvaluation. We follow the method devised by Rhodes-Kropf et al. (2005) to compute such measure. Like Hertzel and Li (2010), we rely on the third valuation model of Rhodes-Kropf et al. (2005) that considers book value of equity, net income, and market leverage ratio as determinants. Our overvaluation measure $(M / V)$ is the logarithm of the ratio between the market value of a firm and its "true value". The fitted estimate of the valuation models is considered the firm's true value. The measure reflects two different sources of overvaluation that are both relevant in our study: the firm-specific error and the time-series sector error. Higher values of $M / V$ indicate more overvaluation, and vice versa. For a particular Dividend change event, $M / V$ is computed using the market value of the firm at 
the end of the sixth day before the event. The day is chosen because it precedes the event and it is the final day of the measurement period for Abnormal return. ${ }^{16}$

In Table 8, we re-estimate the Multinomial Logit models of Tables 2 and 4 , adding $M / V$ and the interaction term between Abnormal return and $M / V$. Most coefficients on this interaction are statistically significant. The signs of the coefficients suggest that firm overvaluation weakens the positive (negative) relationship between recent abnormal returns and the likelihood of positive (negative) changes in dividend payments. This evidence seems to support the notion that managers are less likely to consider past returns when investors tend to misvalue their company and are unreasonably optimistic about its prospects. In other words, managers seem to be able to recognize and disregard changes in stock prices that are driven by transactions from noise traders. More importantly, even after controlling for stock overvaluation, we can still confirm the results of Tables 2 and 4 regarding the interaction terms between Abnormal return and our private information measures.

[Insert Table 8 here]

Table 9 includes OLS regression models with $M / V$ and Abnormal return $\times M / V$. Coefficients for this interaction term are always negative and statistically different from zero in three cases out of four. These results support the conclusions we have drawn above. Moreover, by analyzing the coefficients on the interactions between pre-event abnormal returns and private information measures, we can again confirm the main findings of this study: when deciding quarterly dividend payments, managers seem to give more credence to the information conveyed by past stock price changes if they are likely to be more informative.

\footnotetext{
${ }^{16}$ We obtain qualitatively similar results if we use the market value of the firm at the start of this period, i.e. on the sixth day after the previous quarterly dividend announcement.
} 
[Insert Table 9 here]

\section{Conclusion}

We study the effect of private information in stock prices on the relationship between past abnormal stock returns and current changes in quarterly dividends. Both cash flow and discount rate news on a firm should lead investors to re-estimate the value of the firm and trade its shares accordingly (e.g., Campbell and Shiller, 1988; Chen and Zhao, 2009). Thus, abnormal changes in the market value of a firm are likely to reflect novel information about the firm and should be correlated with future variations in dividend policy. In line with this argument, we report that recent abnormal stock returns have a positive (negative) impact on the likelihood of a quarterly dividend increase (decrease). Further, the current change in quarterly dividends is positively related to past abnormal returns.

More importantly, we find that all these relationships are stronger when stock returns are more likely to convey private information that is new to managers. As measures of private information in stock prices we consider firm-specific stock return variation, the illiquidity ratio by Amihud (2002), the trading measure developed by Llorente et al. (2002), and the probability of informed trading $(P I N)$. Our results are robust to the inclusion of a proxy for managerial private information that we use to control for information conveyed by stock price changes that is already possessed by managers. Similarly, when we control for a measure of stock overvaluation on the market, we can still confirm the main findings of the paper. We also report weaker effects of past returns on current dividend changes when stocks are overvalued. A set of standard determinants of dividend changes is also added to all our specifications. 
The findings reported in this study suggest that novel private information conveyed by stock returns are exploited by managers when deciding the dividend policies of their companies. Our study, therefore, shows the importance of private information in stock prices as a determinant of dividend policy. Moreover, consistent with Kau et al. (2008), our empirical evidence supports the idea that managers "listen to the market" since corporate events and changes in corporate policies are sensitive to market reactions. Our study contributes to the growing literature highlighting the notion that the stock market is not simply a side show but it has, instead, a significant effect on real economic activity through the informational role of stock prices (Bond et al., 2012). In particular, this study highlights that very frequent and significant corporate financial decisions such as dividend payments are affected by changes in financial market variables through an informational channel.

\section{Acknowledgements}

We thank an anonymous referee and seminar participants at the 2014 Financial Management Association meeting in Nashville, the 2014 Asian Finance Association meeting in Bali, and the 2014 Taiwan Finance Association meeting in Hsinchu for their helpful comments. However, the authors are solely responsible for any remaining errors in the paper. 


\section{References}

Allen, F., Michaely, R., 2003. Payout policy. Handbook of the Economics of Finance 1, 337-429. Amihud, Y., 2002. Illiquidity and stock returns: cross-section and time-series effects. Journal of Financial Markets 5, 31-56.

Baker, M., Wurgler, J., 2004. A catering theory of dividends. Journal of Finance 59, 1125-1165.

Bakke, T.E., Whited, TM., 2010. Which firms follow the market? An analysis of corporate investment decisions. Review of Financial Studies 23, 1941-1980.

Benartzi, S., Michaely, R., Thaler, R., 1997. Do changes in dividends signal the future or the past? Journal of Finance 52, 1007-1034.

Bhattacharya, S., 1979. Imperfect information, dividend policy, and "the bird in the hand" fallacy. Bell Journal of Economics 10, 259-270.

Blau, B.M., Fuller, K.P., 2008. Flexibility and dividends. Journal of Corporate Finance 14, 133 152.

Bonaimé, A.A., Hankins, K.W., Harford, J., 2014. Financial flexibility, risk management, and payout choice. Review of Financial Studies 27, 1074-1101.

Bond, P., Edmans, A., Goldstein, I., 2012. The real effects of financial markets. Annual Review of Financial Economics 4, 339-360.

Brav, A., Graham, J.R., Harvey, C.R., Michaely, R., 2005. Payout policy in the 21st century. Journal of Financial Economics 77, 483-527.

Brockman, P., Yan, X., 2009. Block ownership and firm-specific information. Journal of Banking and Finance 33, 308-316.

Brown, J.R., Liang, N., Weisbenner, S., 2007. Executive financial incentives and payout policy: firm responses to the 2003 dividend tax cut. Journal of Finance 62, 1935-1965.

Bulan, L., Subramanian, N., Tanlu, L., 2007. On the timing of dividend initiations. Financial Management 36, 31-65.

Campbell, J.Y., Shiller, R.J., 1988. The dividend-price ratio and expectations of future dividends and discount factors. Review of Financial Studies 1, 195-228.

Chan, K., Chan, Y., 2014. Price informativeness and stock return synchronicity: evidence from the pricing of seasoned equity offerings. Journal of Financial Economics 114, 36-53.

Chan, K., Hameed, A., 2006. Stock price synchronicity and analyst coverage in emerging markets. Journal of Financial Economics 80, 115-147.

Charitou, A., Lambertides, N., Theodoulou, G., 2011. Dividend increases and initiations and default risk in equity returns. Journal of Financial and Quantitative Analysis 46, 15211543.

Chemmanur, T.J., He, J., Hu, G., Liu, H., 2010. Is dividend smoothing universal? New insights from a comparative study of dividend policies in Hong Kong and the U.S. Journal of Corporate Finance 16, 413-430.

Chen, L., Da, Z., Zhao, X., 2013. What drives stock price movements? Review of Financial Studies 26, 841-876.

Chen, L., Zhao, X., 2009. Return decomposition. Review of Financial Studies 22, 5213-5249.

Chen, Q., Goldstein, I., Jiang, W., 2007. Price informativeness and investment sensitivity to stock price. Review of Financial Studies 20, 619-650.

Crawford, S.S., Roulstone, D.T., So, E.C., 2012. Analyst initiations of coverage and stock return synchronicity. Accounting Review 87, 1527-1553. 
Dasgupta, S., Gan, J., Gao, N., 2010. Transparency, price informativeness, and stock return synchronicity: theory and evidence. Journal of Financial and Quantitative Analysis 45, 1189-1220.

DeAngelo, H., DeAngelo, L., Skinner, D.J., 1992. Dividends and losses. Journal of Finance 47, $1837-1863$.

DeAngelo, H., DeAngelo, L., Skinner, D.J., 1996. Reversal of fortune. Dividend signaling and the disappearance of sustained earnings growth. Journal of Financial Economics 40, 341371.

DeAngelo, H., DeAngelo, L., Skinner, D.J., 2008. Corporate payout policy. Foundations and Trends in Finance 3, 95-287.

Defond, M.L., Hung, M., 2004. Investor protection and corporate governance: evidence from worldwide CEO turnover. Journal of Accounting Research 42, 269-312.

Dow, J., Gorton, G., 1997. Stock market efficiency and economic efficiency: is there a connection? Journal of Finance 52, 1087-1129.

Durnev, A., Morck, R., Yeung, B., 2004. Value-enhancing capital budgeting and firm-specific stock return variation. Journal of Finance 59, 65-105.

Durnev, A., Morck, R., Yeung, B., Zarowin, P., 2003. Does greater firm-specific return variation mean more or less informed stock pricing? Journal of Accounting Research 41, 797-836.

Dyck, A., Zingales, L., 2004. Private benefits of control: an international comparison. Journal of Finance 59, 537-600.

Easley, D., Hvidkjaer, S., O’Hara, M., 2002. Is information risk a determinant of asset returns? Journal of Finance 57, 2185-2221.

Fama, E.F., French, K.R., 2001. Disappearing dividends: changing firm characteristics or lower propensity to pay? Journal of Financial Economics 60, 3-43.

Faulkender, M., Wang, R., 2006. Corporate financial policy and the value of cash. Journal of Finance 61, 1957-1990.

Fernandes, N., Ferreira, M.A., 2008. Does international cross-listing improve the information environment. Journal of Financial Economics 88, 216-244.

Fernandes, N., Ferreira, M.A., 2009. Insider trading laws and stock price informativeness. Review of Financial Studies 22, 1845-1887.

Ferreira, D., Ferreira, M.A., Raposo, C.C., 2011. Board structure and price informativeness. Journal of Financial Economics 99, 523-545.

Ferreira, M.A., Laux, P.A., 2007. Corporate governance, idiosyncratic risk, and information flow. Journal of Finance 62, 951-989.

Foucault, T., Fresard, L., 2014. Learning from peers' stock prices and corporate investment. Journal of Financial Economics 111, 554-577.

Fresard, L., 2012. Cash savings and stock price informativeness. Review of Finance 16, 9851012.

Grullon, G., Michaely, R., 2002. Dividends, share repurchases, and the substitution hypothesis. Journal of Finance 57, 1649-1684.

Grullon, G., Michaely, R., Benartzi, S., Thaler, R.H., 2005. Dividend changes do not signal changes in future profitability. Journal of Business 78, 1659-1682.

Grullon, G., Michaely, R., Swaminathan, B., 2002. Are dividend changes a sign of firm maturity? Journal of Business 75, 387-424.

Healy, P.M., Palepu, K.G., 1988. Earnings information conveyed by dividend initiations and omissions. Journal of Financial Economics 21, 149-175. 
Hertzel, M.G., Li, Z., 2010. Behavioral and rational explanations of stock price performance around SEOs: evidence from a decomposition of market-to-book ratios. Journal of Financial and Quantitative Analysis 45, 935-958.

Hutton, A.P., Marcus, A.J., Tehranian, H., 2009. Opaque financial reports, R2, and crash risk. Journal of Financial Economics 94, 67-86.

Jensen, G.R., Lundstrum, L.L., Miller, R.E., 2010. What do dividend reductions signal? Journal of Corporate Finance 16, 736-747.

Jensen, M.C., 1986. Agency costs of free cash flow, corporate finance, and takeovers. American Economic Review 76, 323-329.

Jin, L., Myers, S.C., 2006. R2 around the world: new theory and new tests. Journal of Financial Economics 79, 257-292.

John, K., Williams, J., 1985. Dividends, dilution, and taxes: a signalling equilibrium. Journal of Finance 40, 1053-1070.

Kau, J.B., Linck, J.S., Rubin, P.H., 2008. Do managers listen to the market? Journal of Corporate Finance 14, 347-362.

Kyle, A.S., 1985. Continuous auctions and insider trading. Econometrica 53, 1315-1335.

La Porta, R.L., Lopez-de-Silanes, F., Shleifer, A., Vishny, R.W., 2000. Agency problems and dividend policies around the world. Journal of Finance 55, 1-33.

Lee, D.W., Liu, M.H., 2011. Does more information in stock price lead to greater or smaller idiosyncratic return volatility? Journal of Banking and Finance 35, 1563-1580.

Li, W., Lie, E., 2006. Dividend changes and catering incentives. Journal of Financial Economics 80, 293-308.

Lie, E., 2005. Financial flexibility, performance, and the corporate payout choice. Journal of Business 78, 2179-2202.

Llorente, G., Michaely, R., Saar, G., Wang, J., 2002. Dynamic volume-return relation of individual stocks. Review of Financial Studies 15, 1005-1047.

Luo, Y., 2005. Do insiders learn from outsiders? Evidence from mergers and acquisitions. Journal of Finance 60, 1951-1982.

Miller, M.H., Modigliani, F., 1961. Dividend policy, growth, and the valuation of shares. Journal of Business 34, 411-433.

Miller, M.H, Rock, K., 1985. Dividend policy under asymmetric information. Journal of Finance 40, 1031-1051.

Morck, R., Yeung, B., Yu, W., 2000. The information content of stock markets: why do emerging markets have synchronous stock price movements? Journal of Financial Economics 58, 215-260.

Nissim, D., Ziv, A., 2001. Dividend changes and future profitability. Journal of Finance 56, 2111-2133.

Piotroski, J.D., Roulstone, D.T., 2004. The Influence of analysts, institutional investors, and insiders on the incorporation of market, industry, and firm-specific information into stock prices. Accounting Review 79, 1119-1151.

Rhodes-Kropf, M., Robinson, D.T., Viswanathan, S., 2005. Valuation waves and merger activity: the empirical evidence. Journal of Financial Economics 77, 561-603.

Roll, R., 1988. R2. The Journal of Finance 43, 541-566.

Subrahmanyam, A., Titman, S., 1999. The going-public decision and the development of financial markets. Journal of Finance 54, 1045-1082. 
Watanabe, A., Xu, Y., Yao, T., Yu, T., 2013. The asset growth effect: insights from international equity markets. Journal of Financial Economics 108, 529-563.

Wurgler, J., 2000. Financial markets and the allocation of capital. Journal of Financial Economics 58, 187-214.

Xing, X, Anderson, R., 2011. Stock price synchronicity and public firm-specific information. Journal of Financial Markets 14, 259-276. 


\section{Table 1}

Descriptive statistics.

The table shows descriptive statistics for the dependent and independent variables used in the baseline regression models. Dividend change is the difference between the quarterly dividend payment announced in the current quarter and the quarterly dividend payment announced in the previous quarter, over the announced quarterly dividend for the previous quarter. Abnormal return is the average daily percent abnormal return over the period starting from the sixth trading day after the announcement of the quarterly dividend in the previous quarter and ending on the sixth trading day before the announcement of the quarterly dividend in the current quarter. Daily abnormal return is the daily stock return in excess of the daily value-weighted return for the relevant (based on firm size and book-to-market ratio) Fama-French benchmark portfolio. $\psi=\ln \left(\left(1-R^{2}\right) / R^{2}\right)$, where $R^{2}$ is for a regression of the daily stock return on daily market and industry returns. Illiq is the average daily value of the illiquidity ratio by Amihud (2002). $\gamma$ is the private information trading measure by Llorente et al. (2002). It is the coefficient of the interaction term between the lagged daily stock return and the lagged daily detrended log-turnover from a regression of the daily stock return on the interaction term, the lagged daily stock return, and the daily market return. PIN is the probability of informed trading measure of Easley et al. (2002). For each value of Dividend change, the values of $\psi$, Illiq, $\gamma$, and PIN are for the latest calendar year before the announcement date of the current quarterly dividend. Market capitalization (in billion US dollar and deflated to 1980 using the CPI) is the market value of equity. Market capitalization is measured on the trading day before the day of the current quarterly dividend announcement. Dividend yield is the annual return from dividend payments. Debt is the ratio of long-term debt to total assets. Cash is cash and short-term investments over total assets. Market-to-book is the market value of assets divided by the book value of assets. Operating income is operating income before depreciation over the book value of assets. Dividend premium is the log of the value-weighted average market-to-book ratio of dividend payers minus the log of the valueweighted average market-to-book ratio of non-dividend payers (Baker and Wurgler, 2004). The values of Dividend yield, Debt, Cash, Market-to-book, and Operating income are for the latest fiscal periods ending before the date of the current quarterly dividend announcement while Dividend premium is for the most recent calendar year.

\begin{tabular}{|c|c|c|c|c|c|c|c|c|}
\hline & Obs. & Mean & Min & Median & Max & Skewness & Kurtosis & St. Dev. \\
\hline Dividend Change & 98,535 & 0.0225 & $-8 \mathrm{E}-07$ & 0 & 0.4 & 3.6239 & 16.862 & 0.0674 \\
\hline Abnormal return & 98,535 & 0.0018 & -0.625 & -0.0023 & 0.6983 & 0.123 & 3.1336 & 0.2237 \\
\hline$\psi$ & 98,535 & 1.8549 & -0.9315 & 1.8061 & 5.3702 & 0.2978 & 3.2052 & 1.2162 \\
\hline Illiq & 98,535 & 7.2026 & 0.0039 & 1.8535 & 62.6883 & 2.55 & 9.8919 & 11.9604 \\
\hline$\gamma$ & 94,479 & -0.0025 & -0.2845 & -0.0009 & 0.2646 & -0.0864 & 3.2138 & 0.1035 \\
\hline PIN & 35,359 & 0.1853 & 0.0731 & 0.18 & 0.3566 & 0.5174 & 2.9968 & 0.0597 \\
\hline Dividend yield & 98,535 & 0.0366 & 0.0006 & 0.0251 & 0.135 & 1.1126 & 3.4593 & 0.0326 \\
\hline Market capitalization & 98,535 & 1.6609 & 0.0114 & 0.3528 & 30.3973 & 4.8858 & 29.6319 & 4.2273 \\
\hline Debt & 98,535 & 0.1872 & 0 & 0.1802 & 0.5521 & 0.51 & 2.905 & 0.1266 \\
\hline Cash & 98,535 & 0.0813 & 0.0016 & 0.0518 & 0.441 & 1.9797 & 7.3425 & 0.0845 \\
\hline Market-to-book & 98,535 & 1.4693 & 0.6306 & 1.2143 & 5.3315 & 2.3423 & 9.6826 & 0.8167 \\
\hline Operating income & 98,535 & 0.1674 & 0.0205 & 0.1597 & 0.3987 & 0.6995 & 3.7927 & 0.0704 \\
\hline Dividend premium & 98,535 & 0.0024 & -0.0244 & 0.0029 & 0.0338 & -0.0729 & 2.204 & 0.0142 \\
\hline
\end{tabular}




\section{Table 2}

Firm-specific return variation and dividend changes: Multinomial Logit models.

The table presents Multinomial Logit regression results for the likelihood of an increase (columns (1), (3), and (5)) or a decrease (columns (2), (4), and (6)) in quarterly dividend payments on the pre-event abnormal return, the firm-specific return variation $(\psi)$, the interaction between these two variables, and a set of control variables including two-digit SIC industry dummies (not reported in the table). The base outcome in the model is the zero change in quarterly dividend payments. The dependent variable is based on the continuous variable Dividend change. Definitions for this and all the other variables can be found in Table 1. $z$-statistics adjusted for clustering by firm and calendar month are reported in parentheses. $* * *, * *$, and $*$ denote statistical significance at the $1 \%, 5 \%$, and $10 \%$ level, respectively.

\begin{tabular}{|c|c|c|c|c|c|c|}
\hline & $\begin{array}{c}\text { Dividend } \\
\text { change }> \\
0 \\
(1)\end{array}$ & $\begin{array}{c}\begin{array}{c}\text { Dividend } \\
\text { change }< \\
0\end{array} \\
(2)\end{array}$ & $\begin{array}{c}\text { Dividend } \\
\text { change }> \\
0\end{array}$ & $\begin{array}{c}\text { Dividend } \\
\text { change < } \\
0 \\
(4)\end{array}$ & $\begin{array}{c}\text { Dividend } \\
\text { change }> \\
0\end{array}$ & $\begin{array}{c}\begin{array}{c}\text { Dividend } \\
\text { change }< \\
0\end{array} \\
(6)\end{array}$ \\
\hline Abnormal return & $\begin{array}{c}0.501 * * * \\
(9.719)\end{array}$ & $\begin{array}{c}-1.081 * * * \\
(-6.133)\end{array}$ & & & $\begin{array}{c}0.260^{* * * *} \\
(2.893)\end{array}$ & $\begin{array}{c}-0.523 \\
(-1.612)\end{array}$ \\
\hline$\psi$ & & & $\begin{array}{c}-0.064 * * * * \\
(-4.773)\end{array}$ & $\begin{array}{c}0.021 \\
(0.656)\end{array}$ & $\begin{array}{c}-0.069 * * * \\
(-5.144)\end{array}$ & $\begin{array}{c}0.007 \\
(0.216)\end{array}$ \\
\hline Abnormal return $\times \psi$ & & & & & $\begin{array}{c}0.138 * * * \\
(3.813)\end{array}$ & $\begin{array}{c}-0.267 * * \\
(-2.008)\end{array}$ \\
\hline Dividend yield & $\begin{array}{c}-1.460 * * \\
(-2.129)\end{array}$ & $\begin{array}{c}12.900 * * * \\
(10.473)\end{array}$ & $\begin{array}{c}-1.035 \\
(-1.483)\end{array}$ & $\begin{array}{c}12.660 * * * \\
(10.313)\end{array}$ & $\begin{array}{l}-1.018 \\
(-1.451)\end{array}$ & $\begin{array}{c}12.855^{* * * *} \\
(10.46)\end{array}$ \\
\hline Market capitalization & $\begin{array}{c}0.016 * * * \\
(4.219)\end{array}$ & $\begin{array}{c}-0.078 * * * \\
(-3.026)\end{array}$ & $\begin{array}{c}0.010 * * \\
(2.577)\end{array}$ & $\begin{array}{c}-0.073 * * * * \\
(-2.8)\end{array}$ & $\begin{array}{c}0.010^{* * * *} \\
(2.581)\end{array}$ & $\begin{array}{c}-0.073 * * * \\
(-2.807)\end{array}$ \\
\hline Debt & $\begin{array}{c}0.074 \\
(0.556)\end{array}$ & $\begin{array}{c}0.203 \\
(0.747)\end{array}$ & $\begin{array}{c}0.036 \\
(0.269)\end{array}$ & $\begin{array}{c}0.232 \\
(0.849)\end{array}$ & $\begin{array}{c}0.030 \\
(0.224)\end{array}$ & $\begin{array}{c}0.218 \\
(0.799)\end{array}$ \\
\hline Cash & $\begin{array}{c}0.172 \\
(1.046)\end{array}$ & $\begin{array}{c}-0.466 \\
(-0.911)\end{array}$ & $\begin{array}{c}0.203 \\
(1.221)\end{array}$ & $\begin{array}{c}-0.491 \\
(-0.959)\end{array}$ & $\begin{array}{c}0.182 \\
(1.092)\end{array}$ & $\begin{array}{c}-0.462 \\
(-0.906)\end{array}$ \\
\hline Market-to-book & $\begin{array}{c}-0.052 * * \\
(-2.233)\end{array}$ & $\begin{array}{c}0.286^{* * * *} \\
(3.385)\end{array}$ & $\begin{array}{c}-0.052 * * \\
(-2.252)\end{array}$ & $\begin{array}{c}0.295 * * * \\
(3.568)\end{array}$ & $\begin{array}{c}-0.050 * * \\
(-2.152)\end{array}$ & $\begin{array}{c}0.287 * * * \\
(3.406)\end{array}$ \\
\hline Operating income & $\begin{array}{c}4.576 * * * \\
(19.123)\end{array}$ & $\begin{array}{c}-5.089 * * * \\
(-7.062)\end{array}$ & $\begin{array}{c}4.523 * * * \\
(18.974)\end{array}$ & $\begin{array}{c}-5.112 * * * * \\
(-7.108)\end{array}$ & $\begin{array}{c}4.524 * * * \\
(18.874)\end{array}$ & $\begin{array}{c}-5.069 * * * \\
(-7.028)\end{array}$ \\
\hline Dividend premium & $\begin{array}{c}0.541 \\
(0.369)\end{array}$ & $\begin{array}{c}-3.154 \\
(-0.583)\end{array}$ & $\begin{array}{c}0.188 \\
(0.129)\end{array}$ & $\begin{array}{c}-3.197 \\
(-0.595)\end{array}$ & $\begin{array}{c}0.031 \\
(0.021)\end{array}$ & $\begin{array}{c}-3.061 \\
(-0.566)\end{array}$ \\
\hline Constant & $\begin{array}{c}-2.443 * * * \\
(-40.935)\end{array}$ & $\begin{array}{c}-4.203 * * * \\
(-28.047)\end{array}$ & $\begin{array}{l}-2.312 * * * \\
(-36.212)\end{array}$ & $\begin{array}{c}-4.222 * * * \\
(-23.776)\end{array}$ & $\begin{array}{l}-2.310 * * * \\
(-36.117)\end{array}$ & $\begin{array}{c}-4.229 * * * \\
(-23.833)\end{array}$ \\
\hline Observations & $\begin{array}{l}98,535 \\
0,0210\end{array}$ & $\begin{array}{l}98,535 \\
0,0210\end{array}$ & $\begin{array}{l}98,535 \\
0,019 ?\end{array}$ & $\begin{array}{l}98,535 \\
00192\end{array}$ & $\begin{array}{l}98,535 \\
0,0219\end{array}$ & $\begin{array}{l}98,535 \\
0,0219\end{array}$ \\
\hline
\end{tabular}




\section{Table 3}

Firm-specific return variation and dividend changes: OLS models.

The table presents Ordinary Least Squares regression results for the change in quarterly dividend payments on the pre-event abnormal return, the firm-specific return variation $(\psi)$, the interaction between these two variables, and a set of control variables including two-digit SIC industry dummies (not reported in the table). Observations with zero dividend changes are excluded from the sample. Definitions for all the variables can be found in Table 1. $t$-statistics adjusted for clustering by firm and calendar month are reported in parentheses. $* * *, * *$, and $*$ denote statistical significance at the $1 \%, 5 \%$, and $10 \%$ level, respectively.

\begin{tabular}{|c|c|c|c|}
\hline & \multicolumn{3}{|c|}{ Dividend change } \\
\hline & (1) & (2) & (3) \\
\hline Abnormal return & $\begin{array}{c}0.128 * * * \\
(13.637)\end{array}$ & & $\begin{array}{c}0.076^{* * * *} \\
(4.512)\end{array}$ \\
\hline$\psi$ & & $\begin{array}{c}-0.008 * * * \\
(-3.451)\end{array}$ & $\begin{array}{c}-0.009 * * * \\
(-3.994)\end{array}$ \\
\hline Abnormal return $\times \psi$ & & & $\begin{array}{c}0.029 * * * \\
(3.472)\end{array}$ \\
\hline Dividend yield & $\begin{array}{c}-1.555^{* * *} \\
(-13.710)\end{array}$ & $\begin{array}{c}-1.507 * * * \\
(-13.066)\end{array}$ & $\begin{array}{c}-1.495^{* * *} \\
(-13.174)\end{array}$ \\
\hline Market capitalization & $\begin{array}{c}-0.000 \\
(-1.199)\end{array}$ & $\begin{array}{c}-0.001 * * * \\
(-2.888)\end{array}$ & $\begin{array}{c}-0.001 * * * \\
(-2.687)\end{array}$ \\
\hline Debt & $\begin{array}{c}0.022 \\
(1.020)\end{array}$ & $\begin{array}{c}0.022 \\
(1.003)\end{array}$ & $\begin{array}{c}0.018 \\
(0.809)\end{array}$ \\
\hline Cash & $\begin{array}{c}0.205^{* * * *} \\
(6.326)\end{array}$ & $\begin{array}{c}0.215^{* * *} \\
(6.668)\end{array}$ & $\begin{array}{c}0.209 * * * \\
(6.434)\end{array}$ \\
\hline Market-to-book & $\begin{array}{c}-0.032 * * * \\
(-8.708)\end{array}$ & $\begin{array}{c}-0.032 * * * \\
(-8.877)\end{array}$ & $\begin{array}{c}-0.031 * * * \\
(-8.653)\end{array}$ \\
\hline Operating income & $\begin{array}{c}0.534 * * * \\
(11.506)\end{array}$ & $\begin{array}{c}0.533 * * * \\
(11.326)\end{array}$ & $\begin{array}{c}0.526 * * * \\
(11.319)\end{array}$ \\
\hline Dividend premium & $\begin{array}{c}1.359 * * * \\
(5.674)\end{array}$ & $\begin{array}{c}1.306^{* * *} \\
(5.445)\end{array}$ & $\begin{array}{c}1.300^{* * * *} \\
(5.434)\end{array}$ \\
\hline Constant & $\begin{array}{c}0.233 * * * \\
(5.202)\end{array}$ & $\begin{array}{c}0.253^{* * *} \\
(5.872)\end{array}$ & $\begin{array}{c}0.254 * * * \\
(5.533)\end{array}$ \\
\hline Observations & 16,240 & 16,240 & 16,240 \\
\hline Adjusted $\mathrm{R}^{2}$ & 0.091 & 0.075 & 0.094 \\
\hline
\end{tabular}


Table 4

Alternative private information measures and dividend changes: Multinomial Logit models.

The table presents Multinomial Logit regression results for the likelihood of an increase (columns (1), (3), and (5)) or a decrease (columns (2), (4), and (6)) in quarterly dividend payments on the pre-event abnormal return, a measure of private information in stock prices (alternative to the firm-specific return variation), the interaction between these two variables, and a set of control variables including two-digit SIC industry dummies (not reported in the table). The base outcome in the model is the zero change in quarterly dividend payments. The dependent variable is based on the continuous variable Dividend change. Definitions for this and all the other variables can be found in Table 1. $z$-statistics adjusted for clustering by firm and calendar month are reported in parentheses. ***,**, and * denote statistical significance at the $1 \%, 5 \%$, and $10 \%$ level, respectively.

\begin{tabular}{|c|c|c|c|c|c|c|}
\hline & $\begin{array}{c}\text { Dividend } \\
\text { change }>0\end{array}$ & $\begin{array}{c}\text { Dividend } \\
\text { change }<0\end{array}$ & $\begin{array}{c}\text { Dividend } \\
\text { change }>0\end{array}$ & $\begin{array}{c}\text { Dividend } \\
\text { change }<0\end{array}$ & $\begin{array}{c}\text { Dividend } \\
\text { change > } 0\end{array}$ & $\begin{array}{c}\text { Dividend } \\
\text { change }<0\end{array}$ \\
\hline & (1) & (2) & (3) & (4) & $(5)$ & (6) \\
\hline Abnormal return & $\begin{array}{c}0.400 * * * \\
(6.558)\end{array}$ & $\begin{array}{c}-1.117 * * * \\
(-5.535)\end{array}$ & $\begin{array}{c}0.511 * * * \\
(9.704)\end{array}$ & $\begin{array}{c}-1.076 * * * \\
(-5.942)\end{array}$ & $\begin{array}{c}-0.049 \\
(-0.188)\end{array}$ & $\begin{array}{c}-0.063 \\
(-0.069)\end{array}$ \\
\hline Illiq & $\begin{array}{c}-0.001 \\
(-0.803)\end{array}$ & $\begin{array}{c}0.007 * * \\
(2.455)\end{array}$ & & & & \\
\hline Abnormal return $\times$ Illiq & $\begin{array}{c}0.013 * * * \\
(3.746)\end{array}$ & $\begin{array}{c}0.003 \\
(0.304)\end{array}$ & & & & \\
\hline$\gamma$ & & & $\begin{array}{c}-0.248 * * * \\
(-2.863)\end{array}$ & $\begin{array}{l}-0.515^{*} \\
(-1.726)\end{array}$ & & \\
\hline Abnormal return $\times \gamma$ & & & $\begin{array}{c}0.296 \\
(0.766)\end{array}$ & $\begin{array}{c}-1.680 \\
(-1.103)\end{array}$ & & \\
\hline PIN & & & & & $\begin{array}{c}0.011 \\
(0.029)\end{array}$ & $\begin{array}{l}-2.315^{*} \\
(-1.861)\end{array}$ \\
\hline Abnormal return $\times$ PIN & & & & & $\begin{array}{l}3.202 * * \\
(2.542)\end{array}$ & $\begin{array}{c}-6.386 \\
(-1.338)\end{array}$ \\
\hline Dividend yield & $\begin{array}{c}-1.367 * * \\
(-1.984)\end{array}$ & $\begin{array}{c}12.131 * * * \\
(9.415)\end{array}$ & $\begin{array}{l}-1.364 * \\
(-1.958)\end{array}$ & $\begin{array}{c}12.943 * * * \\
(9.967)\end{array}$ & $\begin{array}{c}-5.458 * * \\
(-2.156)\end{array}$ & $\begin{array}{c}44.737 * * * \\
(8.568)\end{array}$ \\
\hline Market capitalization & $\begin{array}{c}0.015 * * * \\
(3.895)\end{array}$ & $\begin{array}{c}-0.068 * * * \\
(-2.86)\end{array}$ & $\begin{array}{c}0.015 * * * \\
(3.964)\end{array}$ & $\begin{array}{c}-0.074 * * * \\
(-2.97)\end{array}$ & $\begin{array}{c}0.024 * * * \\
(3.688)\end{array}$ & $\begin{array}{c}-0.134 * * * \\
(-2.724)\end{array}$ \\
\hline Debt & $\begin{array}{c}0.068 \\
(0.511)\end{array}$ & $\begin{array}{c}0.274 \\
(1.012)\end{array}$ & $\begin{array}{c}0.084 \\
(0.618)\end{array}$ & $\begin{array}{c}0.212 \\
(0.737)\end{array}$ & $\begin{array}{c}-0.642 * * * \\
(-3.108)\end{array}$ & $\begin{array}{c}0.957 * * \\
(2.073)\end{array}$ \\
\hline
\end{tabular}




\begin{tabular}{|c|c|c|c|c|c|c|}
\hline Cash & $\begin{array}{c}0.178 \\
(1.082)\end{array}$ & $\begin{array}{l}-0.505 \\
(-0.997)\end{array}$ & $\begin{array}{c}0.182 \\
(1.055)\end{array}$ & $\begin{array}{l}-0.839 \\
(-1.566)\end{array}$ & $\begin{array}{c}-0.252 \\
(-0.948)\end{array}$ & $\begin{array}{l}-0.995 \\
(-1.45)\end{array}$ \\
\hline Market-to-book & $\begin{array}{c}-0.053 * * \\
(-2.254)\end{array}$ & $\begin{array}{c}0.302 * * * \\
(3.656)\end{array}$ & $\begin{array}{c}-0.051^{* *} \\
(-2.112)\end{array}$ & $\begin{array}{c}0.294 * * * \\
(3.272)\end{array}$ & $\begin{array}{c}0.046 \\
(1.255)\end{array}$ & $\begin{array}{c}0.474 * * * \\
(3.98)\end{array}$ \\
\hline Operating income & $\begin{array}{r}4.588 * * * \\
(19.062)\end{array}$ & $\begin{array}{c}-5.175^{* * * *} \\
(-7.241)\end{array}$ & $\begin{array}{r}4.654 * * * \\
(18.517)\end{array}$ & $\begin{array}{c}-5.669 * * * \\
(-7.636)\end{array}$ & $\begin{array}{r}4.501 * * * \\
(11.008)\end{array}$ & $\begin{array}{c}-6.547 * * * \\
(-5.853)\end{array}$ \\
\hline Dividend premium & $\begin{array}{c}0.625 \\
(0.423)\end{array}$ & $\begin{array}{l}-3.900 \\
(-0.706)\end{array}$ & $\begin{array}{c}0.758 \\
(0.515)\end{array}$ & $\begin{array}{c}-2.873 \\
(-0.515)\end{array}$ & $\begin{array}{c}-13.654 * * * \\
(-5.552)\end{array}$ & $\begin{array}{c}21.876^{* * *} \\
(3.438)\end{array}$ \\
\hline Constant & $\begin{array}{c}-2.437 * * * \\
(-40.57)\end{array}$ & $\begin{array}{c}-4.259 * * * \\
(-27.674)\end{array}$ & $\begin{array}{c}-2.465^{* * *} \\
(-40.539)\end{array}$ & $\begin{array}{c}-4.113 * * * \\
(-26.753)\end{array}$ & $\begin{array}{c}-2.512 * * * \\
(-19.977)\end{array}$ & $\begin{array}{c}-4.590^{* * * *} \\
(-13.608)\end{array}$ \\
\hline Observations & 98,535 & 98,535 & 94,479 & 94,479 & 35,359 & 35,359 \\
\hline Pseudo-R ${ }^{2}$ & 0.0213 & 0.0213 & 0.0216 & 0.0216 & 0.0320 & 0.0320 \\
\hline
\end{tabular}




\section{Table 5}

Alternative private information measures and dividend changes: OLS models.

The table presents Ordinary Least Squares regression results for the change in quarterly dividend payments on the pre-event abnormal return, a measure of private information in stock prices (alternative to the firm-specific return variation), the interaction between these two variables, and a set of control variables including two-digit SIC industry dummies (not reported in the table). Observations with zero dividend changes are excluded from the sample. Definitions for all the variables can be found in Table 1. $t$-statistics adjusted for clustering by firm and calendar month are reported in parentheses. $* * *, * *$, and $*$ denote statistical significance at the $1 \%, 5 \%$, and $10 \%$ level, respectively.

\begin{tabular}{|c|c|c|c|}
\hline & \multicolumn{3}{|c|}{ Dividend change } \\
\hline & $(1)$ & (2) & (3) \\
\hline Abnormal return & $\begin{array}{c}0.103 * * * \\
(9.601)\end{array}$ & $\begin{array}{c}0.131 * * * \\
(13.485)\end{array}$ & $\begin{array}{l}0.088^{*} \\
(1.776)\end{array}$ \\
\hline Illiq & $\begin{array}{c}0.001 * * * \\
(4.706)\end{array}$ & & \\
\hline Abnormal return $\times$ Illiq & $\begin{array}{c}0.003 * * * \\
(3.288)\end{array}$ & & \\
\hline$\gamma$ & & $\begin{array}{c}0.000 \\
(0.001)\end{array}$ & \\
\hline Abnormal return $\times \gamma$ & & $\begin{array}{c}0.207 * * \\
(2.524)\end{array}$ & \\
\hline PIN & & & $\begin{array}{c}0.301 * * * \\
(5.014)\end{array}$ \\
\hline Abnormal return $\times$ PIN & & & $\begin{array}{c}0.196 \\
(0.768)\end{array}$ \\
\hline Dividend yield & $\begin{array}{c}-1.679 * * * \\
(-15.119)\end{array}$ & $\begin{array}{c}-1.539 * * * \\
(-13.151)\end{array}$ & $\begin{array}{r}-7.331 * * * \\
(-13.858)\end{array}$ \\
\hline Market capitalization & $\begin{array}{c}-0.000 \\
(-0.598)\end{array}$ & $\begin{array}{c}-0.000 \\
(-0.802)\end{array}$ & $\begin{array}{c}0.004 * * * \\
(5.624)\end{array}$ \\
\hline Debt & $\begin{array}{c}0.028 \\
(1.272)\end{array}$ & $\begin{array}{c}0.021 \\
(0.924)\end{array}$ & $\begin{array}{c}-0.097 * * * \\
(-2.777)\end{array}$ \\
\hline Cash & $\begin{array}{c}0.197 * * * * \\
(6.084)\end{array}$ & $\begin{array}{c}0.220 * * * \\
(6.641)\end{array}$ & $\begin{array}{c}0.099 * * \\
(2.240)\end{array}$ \\
\hline Market-to-book & $\begin{array}{c}-0.029 * * * \\
(-8.118)\end{array}$ & $\begin{array}{c}-0.032 * * * \\
(-8.611)\end{array}$ & $\begin{array}{c}-0.037 * * * \\
(-5.789)\end{array}$ \\
\hline Operating income & $\begin{array}{c}0.524 * * * \\
(11.229)\end{array}$ & $\begin{array}{c}0.536 * * * \\
(11.277)\end{array}$ & $\begin{array}{c}0.599 * * * \\
(7.820)\end{array}$ \\
\hline Dividend premium & $\begin{array}{c}1.261 * * * \\
(5.312)\end{array}$ & $\begin{array}{c}1.349 * * * \\
(5.467)\end{array}$ & $\begin{array}{c}-2.617 * * * \\
(-6.183)\end{array}$ \\
\hline Constant & $\begin{array}{c}0.222 * * * \\
(5.544)\end{array}$ & $\begin{array}{c}0.198 * * * \\
(5.291)\end{array}$ & $\begin{array}{c}0.357 * * * \\
(13.070)\end{array}$ \\
\hline $\begin{array}{l}\text { Observations } \\
\text { Adjusted } \mathrm{R}^{2}\end{array}$ & $\begin{array}{c}16,240 \\
0.095\end{array}$ & $\begin{array}{c}15,534 \\
0.091\end{array}$ & $\begin{array}{l}5,203 \\
0.150\end{array}$ \\
\hline
\end{tabular}




\section{Table 6}

Private information in stock prices, earnings announcement return, and dividend changes: Multinomial Logit models.

The table presents Multinomial Logit regression results for the likelihood of an increase (columns (1), (3), (5), and (7)) or a decrease (columns (2), (4), (6), and (8)) in quarterly dividend payments on the pre-event abnormal return, a measure of private information in stock prices, the interaction between these two variables, the average absolute market-adjusted return generated by an earnings announcement $(E R C)$, and the interaction between this variable and the lagged abnormal return. Other control variables (not reported in the table) are Dividend yield, Market capitalization, Debt, Cash, Market-to-book, Operating income, Dividend premium, and two-digit SIC industry dummies. The base outcome in the model is the zero change in quarterly dividend payments. The dependent variable is based on the continuous variable Dividend change. ERC is the average of the absolute market-adjusted returns around quarterly earnings announcements (from day -1 to day +1 ) for the previous calendar year. Definitions for all the other variables can be found in Table 1. $z$-statistics adjusted for clustering by firm and calendar month are reported in parentheses. ***, **, and $*$ denote statistical significance at the $1 \%, 5 \%$, and $10 \%$ level, respectively.

\begin{tabular}{|c|c|c|c|c|c|c|c|c|}
\hline & $\begin{array}{c}\text { Dividend } \\
\text { change }> \\
0 \\
\end{array}$ & $\begin{array}{c}\text { Dividend } \\
\text { change < } \\
0 \\
\end{array}$ & $\begin{array}{c}\text { Dividend } \\
\text { change > } \\
0 \\
\end{array}$ & $\begin{array}{c}\text { Dividend } \\
\text { change < } \\
0 \\
\end{array}$ & $\begin{array}{c}\text { Dividend } \\
\text { change > } \\
0 \\
\end{array}$ & $\begin{array}{c}\text { Dividend } \\
\text { change < } \\
0 \\
\end{array}$ & $\begin{array}{c}\text { Dividend } \\
\text { change }> \\
0 \\
\end{array}$ & $\begin{array}{c}\text { Dividend } \\
\text { change < } \\
0 \\
\end{array}$ \\
\hline & $(1)$ & $(2)$ & (3) & (4) & $(5)$ & $(6)$ & (7) & $(8)$ \\
\hline Abnormal return & $\begin{array}{c}0.196 \\
(1.283)\end{array}$ & $\begin{array}{l}-0.964 * \\
(-1.934)\end{array}$ & $\begin{array}{c}0.335^{* *} \\
(2.556)\end{array}$ & $\begin{array}{c}-1.524 * * * \\
(-3.536)\end{array}$ & $\begin{array}{c}0.356^{* * * *} \\
(2.71)\end{array}$ & $\begin{array}{c}-1.828 * * * \\
(-4.176)\end{array}$ & $\begin{array}{c}-0.210 \\
(-0.608)\end{array}$ & $\begin{array}{c}0.038 \\
(0.033)\end{array}$ \\
\hline$\psi$ & $\begin{array}{c}-0.075 * * * \\
(-5.661)\end{array}$ & $\begin{array}{c}0.017 \\
(0.463)\end{array}$ & & & & & & \\
\hline Abnormal return $\times \psi$ & $\begin{array}{c}0.112^{* * * *} \\
(2.869)\end{array}$ & $\begin{array}{c}-0.344 * * \\
(-2.458)\end{array}$ & & & & & & \\
\hline Illiq & & & $\begin{array}{c}0.003 * * \\
(2.176)\end{array}$ & $\begin{array}{c}-0.005 \\
(-1.253)\end{array}$ & & & & \\
\hline Abnormal return $\times$ Illiq & & & $\begin{array}{c}0.010 * * \\
(2.507)\end{array}$ & $\begin{array}{c}-0.034 * * \\
(-2.457)\end{array}$ & & & & \\
\hline$\gamma$ & & & & & $\begin{array}{l}-0.132 \\
(-1.46)\end{array}$ & $\begin{array}{c}-0.566 \\
(-1.572)\end{array}$ & & \\
\hline Abnormal return $\times \gamma$ & & & & & $\begin{array}{c}0.125 \\
(0.289)\end{array}$ & $\begin{array}{c}-2.531 \\
(-1.459)\end{array}$ & & \\
\hline PIN & & & & & & & $\begin{array}{c}0.045 \\
(0.121)\end{array}$ & $\begin{array}{l}-2.256 * \\
(-1.797)\end{array}$ \\
\hline Abnormal return $\times$ PIN & & & & & & & $3.624 * * *$ & $-8.214 *$ \\
\hline
\end{tabular}




\begin{tabular}{|c|c|c|c|c|c|c|c|c|}
\hline & & & & & & & (2.643) & $(-1.732)$ \\
\hline ERC & $\begin{array}{l}-6.154 * * * \\
(-12.511)\end{array}$ & $\begin{array}{c}9.907 * * * \\
(8.042)\end{array}$ & $\begin{array}{c}-6.469 * * * \\
(-13.11)\end{array}$ & $\begin{array}{c}10.280 * * * \\
(8.041)\end{array}$ & $\begin{array}{c}-6.367 * * * \\
(-12.295)\end{array}$ & $\begin{array}{c}10.155^{* * *} \\
(8.035)\end{array}$ & $\begin{array}{c}-8.663 * * * \\
(-9.331)\end{array}$ & $\begin{array}{c}7.883^{* * * *} \\
(3.496)\end{array}$ \\
\hline Abnormal return $\times \mathrm{ERC}$ & $\begin{array}{c}2.543 \\
(1.381)\end{array}$ & $\begin{array}{c}6.005 \\
(1.217)\end{array}$ & $\begin{array}{c}2.124 \\
(1.144)\end{array}$ & $\begin{array}{c}7.751 \\
(1.556)\end{array}$ & $\begin{array}{c}3.032 \\
(1.595)\end{array}$ & $\begin{array}{l}8.476^{*} \\
(1.664)\end{array}$ & $\begin{array}{c}1.580 \\
(0.505)\end{array}$ & $\begin{array}{c}4.287 \\
(0.489)\end{array}$ \\
\hline Observations & 81,407 & 81,407 & 81,407 & 81,407 & 78,520 & 78,520 & 34,017 & 34,017 \\
\hline Pseudo-R ${ }^{2}$ & 0.0270 & 0.0270 & 0.0262 & 0.0262 & 0.0264 & 0.0264 & 0.0379 & 0.0379 \\
\hline
\end{tabular}




\section{Table 7}

Private information in stock prices, earnings announcement return, and dividend changes: OLS models.

The table presents Ordinary Least Squares regression results for the change in quarterly dividend payments on the pre-event abnormal return, a measure of private information in stock prices, the interaction between these two variables, the average absolute market-adjusted return generated by an earnings announcement $(E R C)$, and the interaction between this variable and the lagged abnormal return. Other control variables (not reported in the table) are Dividend yield, Market capitalization, Debt, Cash, Market-to-book, Operating income, Dividend premium, and two-digit SIC industry dummies. Observations with zero dividend changes are excluded from the sample. $E R C$ is the average of the absolute market-adjusted returns around quarterly earnings announcements (from day -1 to day +1 ) for the previous calendar year. Definitions for all the other variables can be found in Table 1. $t$-statistics adjusted for clustering by firm and calendar month are reported in parentheses. $* * *, * *$, and $*$ denote statistical significance at the $1 \%, 5 \%$, and $10 \%$ level, respectively.

\section{Dividend change}

(1)

0.011
$(0.431)$
$-0.010^{* * *}$
$(-3.827)$
$0.026 * * *$

(2.792)

Illiq

Abnormal return $\times$ Illiq

$\gamma$

Abnormal return $\times \gamma$

PIN

Abnormal return $\times$ PIN

ERC

Abnormal return $\times \mathrm{ERC}$

.069

$(0.572)$

$1.230 * * *$

(2.837)

Observations

Adjusted $\mathrm{R}^{2}$
(2)

(3)

(4)

$-0.003$

$0.041 *$

$0.060 * *$

$(-0.039)$
$0.001 * * *$

(5.894)

$0.003 * * *$

(2.836)

0.008

$(0.463)$

$0.162 *$

(1.808)

$0.322 * * *$

(5.164)

0.291

(1.097)

$-0.271$

$(-1.485)$

1.268

(1.639)

(2.485)

$1.196 * * *$

(2.625)

13,339

5,008

0.086 


\section{Table 8}

Private information in stock prices, stock overvaluation, and dividend changes: Multinomial Logit models.

The table presents Multinomial Logit regression results for the likelihood of an increase (columns (1), (3), (5), and (7)) or a decrease (columns (2), (4), (6), and (8)) in quarterly dividend payments on the pre-event abnormal return, a measure of private information in stock prices, the interaction between these two variables, the log of the ratio between the market value and the "fair value" of equity $(M / V)$, and the interaction between this variable and the lagged abnormal return. Other control variables (not reported in the table) are Dividend yield, Market capitalization, Debt, Cash, Market-to-book, Operating income, Dividend premium, and two-digit SIC industry dummies. The base outcome in the model is the zero change in quarterly dividend payments. The dependent variable is based on the continuous variable Dividend change. Definitions for this and all the other variables except $M / V$ can be found in Table $1 . M / V$ is estimated following Rhodes-Kropf et al. (2005) and their third valuation model. The variable is the sum of the firm-specific error and the time-series sector error. The market value of equity used to find $M / V$ is that at the end of the measurement period of Abnormal return. z-statistics adjusted for clustering by firm and calendar month are reported in parentheses. ***, **, and * denote statistical significance at the $1 \%, 5 \%$, and $10 \%$ level, respectively.

\begin{tabular}{|c|c|c|c|c|c|c|c|c|}
\hline & $\begin{array}{c}\text { Dividend } \\
\text { change }> \\
0\end{array}$ & $\begin{array}{c}\text { Dividend } \\
\text { change < } \\
0\end{array}$ & $\begin{array}{c}\text { Dividend } \\
\text { change }> \\
0\end{array}$ & $\begin{array}{c}\text { Dividend } \\
\text { change < } \\
0 \\
\end{array}$ & $\begin{array}{c}\text { Dividend } \\
\text { change }> \\
0\end{array}$ & $\begin{array}{c}\text { Dividend } \\
\text { change < } \\
0 \\
\end{array}$ & $\begin{array}{c}\text { Dividend } \\
\text { change }> \\
0\end{array}$ & $\begin{array}{c}\text { Dividend } \\
\text { change < } \\
0 \\
\end{array}$ \\
\hline & $(1)$ & $(2)$ & (3) & (4) & $(5)$ & $(6)$ & $(7)$ & $(8)$ \\
\hline Abnormal return & $\begin{array}{c}0.372 * * * \\
(4.034)\end{array}$ & $\begin{array}{l}-0.569 * \\
(-1.772)\end{array}$ & $\begin{array}{c}0.503 * * * \\
(7.8481)\end{array}$ & $\begin{array}{c}-1.145^{* * *} \\
(-5.622)\end{array}$ & $\begin{array}{c}0.588 * * * \\
(10.694)\end{array}$ & $\begin{array}{c}-1.016 * * * \\
(-5.834)\end{array}$ & $\begin{array}{c}0.286 \\
(1.024)\end{array}$ & $\begin{array}{c}-0.125 \\
(-0.135)\end{array}$ \\
\hline$\psi$ & $\begin{array}{c}-0.070 * * * \\
(-5.245)\end{array}$ & $\begin{array}{l}0.011 \\
(0.34)\end{array}$ & & & & & & \\
\hline Abnormal return $\times \psi$ & $\begin{array}{c}0.118 * * * \\
(3.239)\end{array}$ & $\begin{array}{l}-0.215^{*} \\
(-1.659)\end{array}$ & & & & & & \\
\hline Illiq & & & $\begin{array}{c}-0.002 \\
(-1.607)\end{array}$ & $\begin{array}{c}0.007 * * \\
(2.466)\end{array}$ & & & & \\
\hline Abnormal return $\times$ Illiq & & & $\begin{array}{c}0.010 * * * \\
(2.815)\end{array}$ & $\begin{array}{c}0.010 \\
(1.019)\end{array}$ & & & & \\
\hline$\gamma$ & & & & & $\begin{array}{c}-0.244 * * * \\
(-2.826)\end{array}$ & $\begin{array}{c}-0.486 \\
(-1.637)\end{array}$ & & \\
\hline Abnormal return $\times \gamma$ & & & & & $\begin{array}{c}0.257 \\
(0.657)\end{array}$ & $\begin{array}{c}-1.525 \\
(-1.045)\end{array}$ & & \\
\hline PIN & & & & & & & -0.003 & $-2.441 * *$ \\
\hline
\end{tabular}


Abnormal return $\times$ PIN

\begin{tabular}{|c|c|c|c|c|c|c|c|c|}
\hline \multirow{3}{*}{$\mathrm{M} / \mathrm{V}$} & & & & & & & (1.698) & $(-1.209)$ \\
\hline & $-0.146 * * *$ & -0.086 & $-0.145^{* * *}$ & -0.064 & $-0.139 * * *$ & -0.081 & -0.071 & -0.239 \\
\hline & $(-3.549)$ & $(-0.703)$ & $(-3.531)$ & $(-0.5259)$ & $(-3.359)$ & $(-0.665)$ & $(-1.32)$ & $(-1.357)$ \\
\hline \multirow[t]{2}{*}{ Abnormal return $\times \mathrm{M} / \mathrm{V}$} & $-0.317 * * *$ & $0.800 * *$ & $-0.299 * * *$ & $0.918 * * *$ & $-0.367 * * *$ & $0.902 * * *$ & $-0.550 * * *$ & 0.285 \\
\hline & $(-3.949)$ & $(2.566)$ & $(-3.685)$ & $(2.968)$ & $(-4.471)$ & $(2.844)$ & $(-4.285)$ & $(0.504)$ \\
\hline Observations & 98,535 & 98,535 & 98,535 & 98,535 & 94,479 & 94,479 & 35,359 & 35,359 \\
\hline Pseudo- $\mathrm{R}^{2}$ & 0.0227 & 0.0227 & 0.0220 & 0.0220 & 0.0225 & 0.0225 & 0.0327 & 0.0327 \\
\hline
\end{tabular}




\section{Table 9}

Private information in stock prices, stock overvaluation, and dividend changes: OLS models.

The table presents Ordinary Least Squares regression results for the change in quarterly dividend payments on the pre-event abnormal return, a measure of private information in stock prices, the interaction between these two variables, the $\log$ of the ratio between the market value and the "fair value" of equity $(M / V)$, and the interaction between this variable and the lagged abnormal return. Other control variables (not reported in the table) are Dividend yield, Market capitalization, Debt, Cash, Market-to-book, Operating income, Dividend premium, and twodigit SIC industry dummies. Observations with zero dividend changes are excluded from the sample. $M / V$ is estimated following Rhodes-Kropf et al. (2005) and their third valuation model. The variable is the sum of the firmspecific error and the time-series sector error. The market value of equity used to find $M / V$ is that at the end of the measurement period of Abnormal return. Definitions for all the other variables can be found in Table 1. $t$-statistics adjusted for clustering by firm and calendar month are reported in parentheses. ***, **, and * denote statistical significance at the $1 \%, 5 \%$, and $10 \%$ level, respectively.

Dividend change

(1)

$\begin{array}{lc}\text { Abnormal return } & 0.084 * * * \\ & (4.858) \\ \psi & -0.009 * * * \\ & (-3.900) \\ \text { Abnormal return } \times \psi & 0.025 * * * \\ & (3.030)\end{array}$

Illiq

Abnormal return $\times$ Illiq

$\gamma$

Abnormal return $\times \gamma$

PIN

Abnormal return $\times$ PIN

$\mathrm{M} / \mathrm{V}$

Abnormal return $\times \mathrm{M} / \mathrm{V}$

Observations

Adjusted $\mathrm{R}^{2}$

16,240
(2)

$\begin{array}{ccc}0.106^{* * *} & 0.133^{* * *} & 0.109 * * \\ (9.365) & (13.430) & (2.074)\end{array}$

$0.001 * * *$

(4.825)

$0.002 * * *$

(2.659)

$(-0.093)$

$0.196 * *$

(2.394)

$0.309 * * *$

(5.114)

0.112

(0.429)

0.015

0.009

0.005

(1.314)

$-0.048 * *$

(0.565)

$-0.050$

(-2.254)

(-2.742)

(-1.193)

16,240

15,534

5,203

0.096

0.092

0.151 